Graziele G. Bovi, Oluwafemi J. Caleb, Manfred Linke, Cornelia Rauh, Pramod V. Mahajan

\title{
Transpiration and moisture evolution in packaged fresh horticultural produce and the role of integrated mathematical models: A review
}

Journal article | Accepted manuscript (Postprint)

This version is available at https://doi.org/10.14279/depositonce-9718

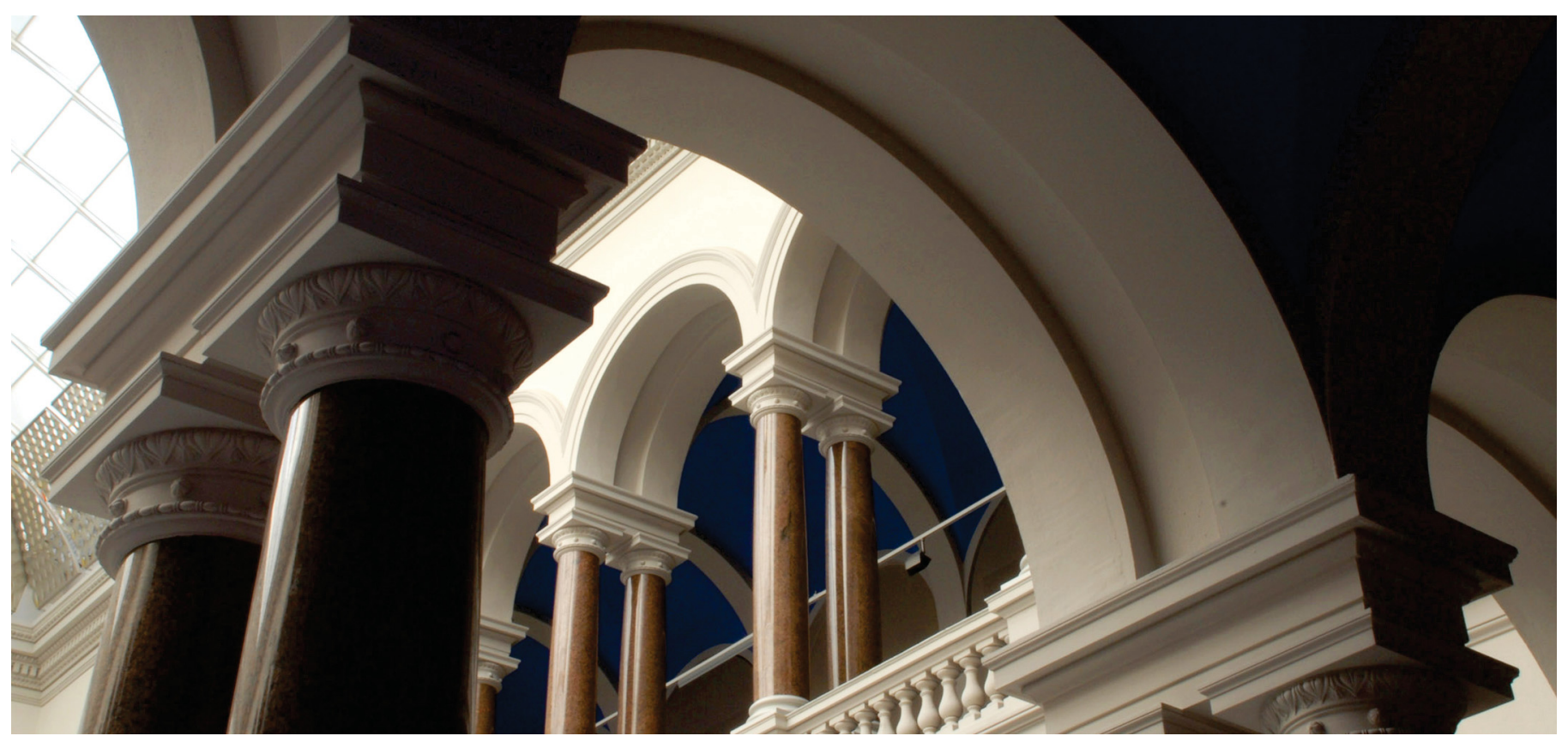

Bovi, G. G., Caleb, O. J., Linke, M., Rauh, C., \& Mahajan, P. V. (2016). Transpiration and moisture evolution in packaged fresh horticultural produce and the role of integrated mathematical models: A review. Biosystems Engineering, 150, 24-39. https://doi.org/10.1016/j.biosystemseng.2016.07.013 
1 Transpiration and moisture evolution in packaged fresh

2 horticultural produce and the role of integrated

3 mathematical models: A review

4

5 In: Biosystems Engineering, 150, 24-39.

6

7

8 Cite as: Bovi, G. G., Caleb, O., Linke, M., Rauh, C., \& Mahajan, P. (2016). Transpiration and

9 moisture evolution in packaged fresh horticultural produce and the role of integrated

10 mathematical models: A review. Biosystems Engineering, 150, 24-39.

11 doi: https://doi.org/10.1016/j.biosystemseng.2016.07.013

12

13

14

15

16

17

18

19

20

21

22

23

24

25

26

27

28

29

30

31

32

33

34

35

36

37 


\section{Transpiration and moisture evolution in packaged fresh horticultural produce and the role of integrated mathematical models: A review}

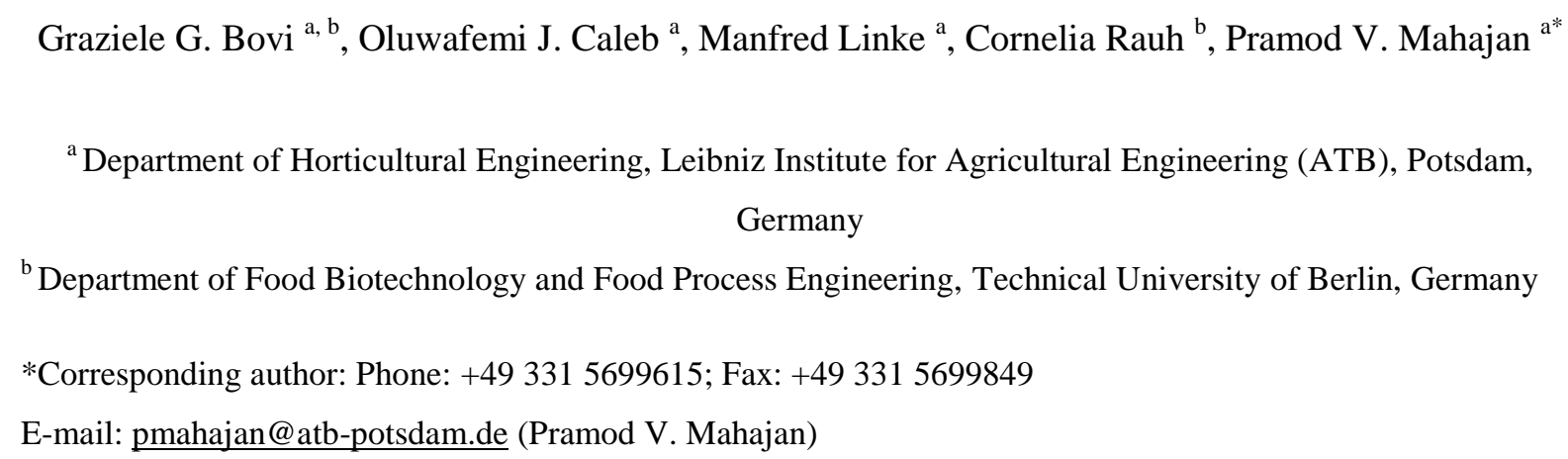

\section{Abstract}

Transpiration has various adverse effects on postharvest quality and the shelf-life of fresh fruit and vegetables (FFV). If not controlled, the water released through this process results in direct mass loss and moisture condensation inside packaged FFV. Condensation represents a threat to the product quality as water may accumulate on the product surface and/or packaging system, causing defects in external appearance and promoting growth of spoilage microorganisms. Thus, moisture regulation is extremely important for extending FFV shelflife. This review focuses on transpiration phenomenon and moisture evolution in packaged fresh horticultural produce. It provides recent information on various moisture control strategies suitable for packaging of fresh horticultural produce. It also provides an evaluation on the role and application of integrative mathematical modelling in describing water relations of FFV for packaging design, as well as, an overview of models reported in literature.

Keywords: Moisture loss; packaging; humidity control; mathematical modelling; fresh produce; condensation 


\section{Introduction}

72 Fresh horticultural produce are highly perishable commodities, as they remain metabolically active even after harvest. Fresh produce continues to lose water due to transpiration and respiration process. This turns produce shelf-life into a race against the clock for growers, processors, and retailers to maintain quality and reduce food loss (Mahajan, Caleb, Singh, Watkins, \& Geyer, 2014). This water loss is usually associated with economic loss since it causes a decrease in saleable mass, due to shrivelling of the product (Caleb, Mahajan, AlSaid, \& Opara, 2013; Veraverbeke, Verboven, Van Oostveldt, \& Nicolaï, 2003b). In addition, moisture loss of the fresh produce can accumulate on the product surface and/or packaging system, causing defects in external appearance and promoting growth of spoilage microorganisms (Kang \& Lee, 1998; Linke \& Geyer, 2013). This leads to quality deterioration and flavour loss. Hence, it is important to remove or avoid moisture condensation on the product in order to maintain quality and prevent the growth of spoilagecausing microorganisms (Powers \& Calvo, 2003).

According to Fonseca, Oliveira, and Brecht (2002) the goals of postharvest technology are to maintain freshness quality and reduce losses in the postharvest value chain of fresh fruit and vegetables (FFV). Temperature control and modification of atmosphere are important factors to extend a products shelf life (Fonseca et al., 2002). Nevertheless, besides these two factors the control of storage or in-package relative humidity $(\mathrm{RH})$ is of critical importance (Tano, Oulé, Doyon, Lencki, \& Arul, 2007). For example, Rux et al. (2015) investigated the transpiration behaviour of mushroom under different temperature and $\mathrm{RH}$, and determined the effect of salt embedded humidity-regulating tray on in-package humidity and condensation behaviour. The authors reported that the humidity-regulating tray absorbed part of the water vapour produced by mushroom during the $6 \mathrm{~d}$ of storage, but its regulatory capacity was not efficient to avoid in-package moisture condensation. Therefore, understanding the physiological response of individual fresh horticultural produce towards optimum packaging/storage system design with adequate humidity control is one of the keys to achieving the postharvest technology goals.

99 Furthermore, mathematical modelling plays an important role in predicting the physiological

100 response of FFV under different storage conditions. Mathematical models offer the possibility 101 to describe characteristic changes in biological systems as a function of different environmental conditions, without the need to access these conditions in real time (Castellanos \& Herrera, 2015). This makes it possible to optimise packaging design under different storage conditions for FFV (Kang \& Lee, 1998), and to estimate the packaging 
requisites for specific fresh produce (Caleb et al., 2013; Sousa-Gallagher, Mahajan, \&

106 Mezdad, 2013).

107 In this context, the aim of this article is to provide a comprehensive review regarding the transpiration phenomenon and moisture evolution inside packaged fresh horticultural produce. The role and application of integrative mathematical modelling in describing water relations of fresh horticultural produce for packaging design is discussed. In addition, an overview of

111 the various moisture control strategies, mathematical models reported in literature, and future 112 prospects is presented.

\section{Transpiration phenomenon in fresh horticultural produce}

115 Transpiration is a critical physiological process for FFV (Xanthopoulos, Athanasiou, Lentzou, 116 Boudouvis, \& Lambrinos, 2014). Once separated from the mother plant, FFV cannot replace 117 water from the plant and/or soil and depend on their own water content for transpiration and 118 organic substrate for respiration (Caleb et al., 2013). Transpiration phenomenon involves 119 three main stages: i) moisture is transported as liquid and vapour from intercellular spaces to 120 and through the skin of the product; ii) moisture is evaporated from the outer surface layer of 121 the product; and iii) convective mass transfer of the moisture to the surroundings (Becker \& 122 Fricke, 2001; Veraverbeke, Verboven, Van Oostveldt, \& Nicolaï, 2003a). In terms of plant 123 physiology there are four FFV components involved in the transpiration process this include:

124 a) intercellular air spaces, through where water vapour diffuses inside the FFV; b) cuticle, 125 responsible for the transpiration in which liquid water moves to the cell walls on the cuticle 126 side of epidermal cells; where it can evaporate and the vapour is then diffused across the 127 cuticle; c) stomata, through where water vapour diffuses in order to reach the boundary layer; 128 and, d) boundary layer, which is located at the leaf surface and is the final component 129 encountered by diffusing water vapour (Nobel, 2009).

130 Transpiration is driven by a concentration difference and can be described in terms of water 131 activity differences across the membrane, moisture concentration and water vapour pressure 132 differences between a product's surface and its surrounding (Becker \& Fricke, 2001; 133 Veraverbeke et al., 2003a, 2003b). Based on this definition, there should theoretically be no 134 potential for transpiration phenomenon at $100 \% \mathrm{RH}$ (i.e. saturated storage condition) and 135 constant temperature since there is no water vapour pressure difference. However, this is not 136 the case for saturated conditions as transpiration occurs due to the heat generated by the 137 respiration process (Becker \& Fricke, 1996; Sastry, Baird, \& Buffington, 1977; Tano, 
138 Kamenan, \& Arul, 2005). Recently, Mahajan et al. (2016) investigated the moisture loss 139 behaviour of three different FFV and a dummy evaporation sphere stored at $13{ }^{\circ} \mathrm{C}, 100 \% \mathrm{RH}$. 140 Results showed that despite water vapour saturation the three tested products lost mass at $141 \quad 100 \% \mathrm{RH}$, while no mass was lost from the evaporating sphere. These results agree with the 142 hypothesis that respiratory heat can significantly influence moisture evolution from FFV 143 under saturated conditions. This implies that transpiration in packaged fresh produce 144 continues where water vapour saturation is commonly observed. It also indicates that the 145 transpiration process under saturated conditions is a complex process that involves different 146 heat components including respiratory heat generated by the product; evaporative cooling 147 effect on the product's surface; convective heat transfer between the product and its 148 surrounding environment.

\subsection{Potential effect on postharvest quality of fresh horticultural produce}

151 Transpiration phenomenon causes both water loss and evolution of free water from FFV, 152 which may lead to formation of moisture condensation on the surface of product and/or 153 packaging material. The free water, also known as moisture, facilitates the growth of fungal 154 and bacterial pathogens (Holcroft, 2015; Linke \& Geyer, 2013). Water loss results in direct 155 mass loss, shrivelling, gloss reduction, limpness and wilting of horticultural produce. As the 156 produce continues to lose water, its appearance, quality, shelf life, profitability, and consumer 157 appeal diminishes (Holcroft, 2015; Thompson, Mitchell, Rumsay, Kasmire, \& Crisosto, 158 1998).

159 Water loss affects FFV in different degrees. According to Holcroft (2015), leafy vegetables 160 wilt after approximately $3-5 \%$ of water loss, while for nectarines shrivelling occur after $19 \%$ 161 of water loss. There is extensive literature stating the maximum permissible water loss (\%) for 162 a wide range of FFV (Kays \& Paull, 2004; Robinson, Browne, \& Burton, 1975; Thompson et al., 1998). For instance, the maximum permissible mass loss for grape and nectarine is 5\%

164 and 21\%, respectively (Kays \& Paull, 2004). For summer squash the permissible mass loss is $16524 \%$, while for broccoli and carrot with leaves it is 4\% (Thompson et al., 1998). Also, fresh 166 produce response to transpiration such as biochemical, microbiological, and physiological 167 changes contribute to quality degradation. These responses are usually temperature dependent 168 and affect transpiration of FFV and low $\mathrm{RH}$ can raise transpiration damage leading to 169 dehydration, increased respiratory intensity, and loss of product quality (Castellanos \& 
Herrera, 2015). Therefore, optimum temperature and RH should be maintained for each product in order to extend shelf-life and maintain products quality.

\subsection{Transpiration measurement}

174 Water loss from FFV, also known as moisture loss or transpiration phenomena, is often expressed as the percentage change in mass of the original or initial product mass. The quantity of water loss over a given period of time is considered as the water loss rate, also referred to as rate of moisture loss or transpiration rate (TR) (Maguire, Banks, \& Opara, 2001). Calculation of the TR based on moisture loss per unit time is the most used and reported method to describe transpiration phenomenon in fresh horticultural produce (Caleb et al., 2013; Castellanos \& Herrera, 2015; Mahajan, Oliveira, \& Macedo, 2008a; Shirazi \& Cameron, 1993; Sousa-Gallagher et al., 2013).

However, there are two main possible approaches to calculate TR of fresh produce. The first approach is by gravimetric measurement of change in product mass over time. The second approach is based on theoretical determination of TR, via the Fick's law of diffusion. It is worth mentioning that the gravimetric measurement of TR is used by many authors to find other parameters, such as the transpiration coefficient and/or tissue and boundary layer resistance that better describes the transpiration phenomenon (Linke, 1997; Sastry \& Buffington, 1983; Thompson et al., 1998).

\subsubsection{Gravimetric approach}

The most commonly reported method for measuring TR is by the gravimetric approach, also known as the mass loss approach, which involves periodically weighing the produce at a given temperature and RH. TR can be directly calculated per unit surface area $\left(T R_{S}\right)($ Eq. 1) and/or per unit of initial mass $\left(T R_{m}\right)$ (Eq. 2) of the produce:

$$
\begin{aligned}
& T R_{s}=\frac{M_{i}-M_{t}}{t \cdot A_{s}} \\
& T R_{m}=\frac{M_{i}-M_{t}}{t \cdot M_{i}}
\end{aligned}
$$

where $M_{i}$ is the initial mass of the product; $M_{t}$ is product mass at a determined time (t); and $A_{s}$ is the initial surface area of the product. Usually $T R_{S}$ is commonly expressed in $\mathrm{mg} \mathrm{cm}^{-2} \mathrm{~h}^{-1}$ or $\mathrm{mg} \mathrm{cm} \mathrm{s}^{-1}$ and $T R_{m}$ in $\mathrm{g} \mathrm{kg}^{-1} \mathrm{~h}^{-1}, \mathrm{mg} \mathrm{kg}^{-1} \mathrm{~h}^{-1}$ or $\mathrm{mg} \mathrm{kg}^{-1} \mathrm{~s}^{-1}$.

Different experimental methods have been reported for the measurement of TR by the mass

201 loss approach (Fig. 1). In some setups, the balance was located outside the experimental 202 container, which limits continuous measurement of product mass loss. In these cases the 
product has to be taken out of the container to be measured and opening of the container can result in disturbance of internal atmosphere and $\mathrm{RH}$ if it is not carried out with caution (Xanthopoulos et al., 2014). In the experiment conducted by Kang and Lee (1998), the chamber was equipped with gas control to maintain the desired oxygen $\left(\mathrm{O}_{2}\right)$ and carbon dioxide $\left(\mathrm{CO}_{2}\right)$ concentration in order to incorporate the effect of modified atmosphere as one of the parameters of TR for apples and minimally processed cut vegetables. A novel setup was considered by Mahajan et al. (2016) in their study. The authors included an additional infrared temperature sensor to monitor the products' surface temperature and a sensor for the surrounding environmental conditions.

\subsubsection{Theoretical approach}

214 It is well established that transpiration can be visualised as the interaction between a driving 215 force for mass loss and resistance (Becker \& Fricke, 1996, 2001; Leonardi, Baille, \& 216 Guichard, 2000; Sastry, 1985; Sastry \& Buffington, 1983). This interaction is expressed 217 mathematically as:

$$
T R_{m}=k_{t} \cdot\left(P_{s}-P_{\infty}\right)
$$

219 where $T R_{m}$ is transpiration rate, mass basis $\left(\mathrm{mg} \mathrm{kg}^{-1} \mathrm{~s}^{-1}\right) ; k_{t}$ is transpiration coefficient assumed 220 constant for a specific product $\left(\mathrm{mg} \mathrm{kg}^{-1} \mathrm{~s}^{-1} \mathrm{MPa}^{-1}\right) ; P_{s}$ is water vapour pressure at the 221 evaporating surface of the product (MPa); and $P_{\infty}$ is ambient water vapour pressure (MPa). In this mathematical equation the driving force for transpiration is represented by $\left(P_{s}-P_{\infty}\right)$, which is also known as the water vapour pressure deficit (VPD), and the resistance represented by the inverse of the transpiration coefficient $\left(\mathrm{k}_{\mathrm{t}}\right)$. The $\mathrm{k}_{\mathrm{t}}$ can be divided into two terms, as follows:

$$
\frac{1}{k_{t}}=\frac{1}{k_{s}}+\frac{1}{k_{a}}
$$

where $k_{s}$ is skin mass transfer (transpiration) coefficient $\left(\mathrm{mg} \mathrm{kg}^{-1} \mathrm{~s}^{-1} \mathrm{MPa}^{-1}\right)$ and $k_{a}$ is air film mass transfer $\left(\mathrm{mg} \mathrm{kg}^{-1} \mathrm{~s}^{-1} \mathrm{MPa}^{-1}\right)$, also known as convective mass transfer coefficient or external mass transfer coefficient. Combining Eq. 3 with Eq. 4 yields:

$$
T R_{m}=\frac{P_{s}-P_{\infty}}{\frac{1}{k_{s}}+\frac{1}{k_{a}}}
$$

231 What differ among authors in using Eq. 5, are the factors and assumptions that are considered 232 important or negligible in order to calculate $k_{s}$ and $k_{a}$. In Sastry and Buffington (1983), these 233 coefficients were represented by $k_{s}=\frac{\tau}{\delta \varphi}$ and $k_{a}=\frac{1}{h_{d}}$, where $\delta$ is the diffusion coefficient of water vapour in air; $\tau$ the product skin thickness; $\varphi$ is fraction of product surface covered by 
pores; and $h_{d}$ is convective mass transfer coefficient. In contrast, Fockens and Meffert (1972) expressed skin mass transfer coefficient as $k_{s}=\frac{\xi_{1} \beta}{R_{D} T}$ and air film mass transfer as $k_{a}=$ $\frac{\xi_{2}}{1 / \beta^{+}{ }^{\mu S} / \delta}$, where $\xi_{1}$ is a fraction of surface behaving as a free water zone (non-dimensional); $\beta$ 238 is a convective mass transfer coefficient $\left(\mathrm{m} \mathrm{s}^{-1}\right) ; R_{D}$ is a universal gas constant $\left(\mathrm{J} \mathrm{kg}^{-1}{ }^{\circ} \mathrm{C}^{-1}\right) ; T$ 239 is the ambient temperature $\left({ }^{\circ} \mathrm{C}\right)$; $\xi_{2}$ fraction of surface behaving as porous membrane (non240 dimensional); $\mu$ is resistance factor (non-dimensional); $s$ is skin thickness (m); and $\delta$ is diffusion coefficient of water vapour in the air $\left(\mathrm{m}^{2} \mathrm{~s}^{-1}\right)$.

242 Different ranges of transpiration coefficients are shown in Table 1. Limitations of using transpiration coefficients are that they are restricted to certain range of experimental conditions; and often product specific. For example, there is a significant difference in transpiration coefficient of carrot ranging from 106 to $3250 \mathrm{mg} \mathrm{kg}^{-1} \mathrm{~s}^{-1} \mathrm{MPa}^{-1}$, based on various assumptions adopted in the calculation (Linke \& Geyer, 2001). Also, different experimental methods are used for determining the transpiration coefficient, which results in different values even for the same product (Sastry \& Buffington, 1983). However, Eq. 3 is a simple mathematical equation that can be used to predict the TR of a specific product. In order to use this equation details on transpiration coefficient of the specific product and the calculated water pressure difference between the FFV and surrounding environment are required. To determine the ambient water vapour pressure, psychrometric charts, which relate temperature, $\mathrm{RH}$ and water vapour pressure can be used.

254 A similar approach to determine the TR of FFV is by the use a known tissue and boundary 255 layer resistance. Figure 2 presents the dynamics of water loss rate during the postharvest storage of FFV in this approach at constant heat and mass transfer conditions, and under predefined experimental conditions. The first section is characterised by the atmospheric evaporation of free surface water from the product. In this case the intensity of transpiration is solely dependent on the boundary layer resistance. However, when free water is no longer on the surface, water is transported from inside the produce to the surface, but with an additional resistance due to internal membranes, called tissue resistance. This additional resistance is evident by the decrease in the slope of water loss rate over time as shown in the second section. At this point, the water potential of the produce is also reduced, as shown in the third section (Linke, 1997). The reduction in water potential is important because the flow of liquid and/or gaseous water out of a produce, tissue or plant cell, as well as the rate of water movement directly depends on the water potential gradient between the produce, tissue, or plant cell and the surroundings (Gomez Galindo, Herppich, Gekas, \& Sjoholm, 2004: Nobel, 
2009). Water potential can be defined as the free energy of water within the respective system, such as produce, tissue, plant cell, or solution compared to that of pure water (Rodov et al., 2010). Thus, water potential is indicative of the true water deficit of a system (Herppich, Mempel, \& Geyer, 1999). In addition, in plant physiology, water potential is generally accepted as the best parameter to describe actual tissue water status (Herppich, Mempel, \& Geyer, 2001).

In this approach the resistances in the water vapour pathway can be determined by using a modified Fick's law in terms of resistances, as shown in Eqs. 6 and 7, while taking into consideration the conditions presented in section 1 and 2 (Fig. 2).

$$
T R_{S}=\frac{x_{p}-x_{A}}{r_{B}+r_{T}}
$$

where $T R_{S}$ is transpiration rate, area basis $\left(\mathrm{mg} \mathrm{cm}^{-2} \mathrm{~s}^{-1}\right) ; x_{P}$ is volume related water content of air in the intercellular spaces in the centre of the produce $\left(\mathrm{mg} \mathrm{cm}^{-3}\right) ; x_{A}$ is volume related water content of the air unaffected by the produce $\left(\mathrm{mg} \mathrm{cm}^{-3}\right) ; r_{B}$ is boundary layer resistance in the water vapour pathway $\left(\mathrm{s} \mathrm{cm}^{-1}\right)$; and $r_{T}$ is tissue resistance in the water vapour pathway $\left(\mathrm{s} \mathrm{cm}^{-1}\right)$, which includes tissue and skin of the fruit or vegetable. However, the tissue resistance approach becomes negligible when produce surface is wet and therefore the following equation is valid:

$$
T R_{S}=\frac{x_{p s}-x_{A}}{r_{B}}
$$

where $x_{p s}$ is the water content of the air at the produce surface, $\mathrm{mg} \mathrm{cm}^{-3}$ (Fig. 3). Tissue resistance is determined by the nature of the plant tissue, which is exclusively dependent on the internal properties of the product, such as the water activity and sugar. Other factors influencing tissue resistance of horticultural produce include pre-harvest conditions and postharvest handling practices (Linke, 1997).

On the other hand, the boundary layer resistance is determined by the form of FFV epidermal layer. It is dependent on external parameters such as shape, dimensions, and surface structure of the product, as well as environmental conditions such as air flow conditions and surface temperature of the produce. For the determination of the boundary layer resistance the water loss rate has to be measured under natural convection. Once boundary layer resistance is known, tissue resistance can be determined by Eq. 6, as long as the centre of the produce is water saturated. In Table 2 it is possible to visualise different tissue resistance found by Linke and Geyer (2000). The boundary layer resistance for single produce items at unrestricted natural convection and room temperatures was in the range between 1 and $4 \mathrm{~s} \mathrm{~cm}^{-1}$ for small 
and bigger FFV, respectively. Both theoretical approaches for estimating TR, via transpiration coefficient or tissue resistance, have specific limitations due to the different values found in the literature. However, they are very useful tools to calculate the TR of FFV since no experimental data is required.

\subsection{Factors affecting transpiration}

\subsubsection{Intrinsic factors}

Fresh produce shape and size, expressed as surface area-to-volume or surface area-to-mass ratios, are major factors affecting the $T R_{m}$, especially the boundary layer resistance. Products with large surface area to mass ratios provide a considerable contact area with surrounding atmosphere. For example, horticultural products, such as leafy green vegetables and cauliflowers have higher $T R_{m}$, when compared to spherical produce such as oranges and tomatoes with lower surface area (Sastry, 1985). Similarly, morphological and anatomical characteristics of the FFV also have significant effect on TR, specifically on the tissue resistance. Surface structure for each FFV is unique and those which contain skin and/or a waxy coating such as apple, provide extra layers of resistance and therefore the water loss rate in this product is lower than for products without these structures such as mushroom (Sastry, 1985). The skin of FFV acts as a barrier to diffusion of water vapour (Maguire et al., 2001).

Purity level of water content in FFV can also affect the TR of the product. Water content in most FFV contains dissolved/soluble solids (i.e. total soluble solids). Literature has extensively shown that total soluble solids of FFV significantly differs (Beckles, 2012; Mahmood, Anwar, Abbas, Boyce, \& Saari, 2012). Thus, vapour pressure at the evaporating surface is determined by Raoult's law and is a little lower than the saturation water vapour pressure at the same temperature (Sastry, 1985). This effect is also known as the vapour pressure lowering effect since it causes a reduction in VPD and directly affects the TR.

Additionally, physiological condition, such as the maturity stage in fresh produce after harvest has been shown to significantly influence on TR. In general, immature and over mature fruit transpires more rapidly than optimally mature fruit due to the permeability of the skin to water vapour (Mishra \& Gamage, 2007; Sastry, 1985). The developmental stages of the fruit therefore directly affect the tissue resistance of the product. However, factors are often eliminated as a variable on mathematical models of transpiration due to lack of a reliable quantitative maturity index (Sastry \& Buffington, 1983). 


\subsubsection{Extrinsic factors}

334 Impacts of factors such as temperature and RH on TR of fresh horticultural produce have been extensively investigated over the last decade. Mahajan et al. (2008a) found that by increasing the $\mathrm{RH}$ in the storage containers for whole mushrooms from $76 \%$ to $96 \%$, TR decreased by $87 \%$ at $4{ }^{\circ} \mathrm{C}$, whereas decreasing the temperature from $16{ }^{\circ} \mathrm{C}$ to $4{ }^{\circ} \mathrm{C}$ decreased the TR by $61 \%$ at $96 \%$ RH. Caleb et al. (2013) also showed that by increasing RH inside storage containers for pomegranate arils from $76 \%$ to $96 \%$, decreased TR by $83.5 \%$ at $5{ }^{\circ} \mathrm{C}$, while decreasing the temperature from $15{ }^{\circ} \mathrm{C}$ to $5{ }^{\circ} \mathrm{C}$, TR decreased by $68.9 \%$. Xanthopoulos et al. (2014) reported that the TR for grape tomatoes increased with temperature from $15{ }^{\circ} \mathrm{C}$ to 20 ${ }^{\circ} \mathrm{C}$, while it decreased for $\mathrm{RH} 80 \%$ to $92 \%$. These studies showed that humidity is the variable with the greatest effect on TR, and the magnitude of TR decrease is product dependent. Aguirre, Frias, Barry-Ryan, and Grogan (2009) expressed the visual quality of mushroom stored under different temperatures and humidity using VPD instead of the RH to avoid the interaction between temperature and RH. Although VPD is a conventional variable for refrigeration technology, package designers and food technologists usually employ the RH.

Airflow around fresh produce and/or through the packaged product, also have a significant influence on TR. Baltaci, Linke, and Geyer (2010) measured the water loss rate of artificial fruits (water filled evaporating spheres) inside a plastic box in three layers under natural convection and forced airflow $\left(0.8 \mathrm{~m} \mathrm{~s}^{-1}\right)$. The authors showed that differences in TR were dependent on the produce position inside and airflow. They also found that TR was higher under forced airflow than under natural convective conditions. Air movement around the product prevents the development of a microenvironment with high-humidity build-up (Sastry, 1985), and this decreases the resistance of the air films to mass transfer.

356 Physical conditions and surface injuries such as cuts, bruises and scratches on the skin surface of FFV, tend to increase the TR, as they reduce the tissue resistance due to modification of the skin (Holcroft, 2015; Maguire et al., 2001). FFV have 2 to 3 times higher TR after harvest when compared to the steady state values due to the physical injuries caused by detachment from the mother plant (Sastry et al., 1977). However, during the storage period once the injuries are healed TR reduces to a lower and relatively steady value (Sastry, 1985).

362 Also, heat removed from the evaporating surface during transpiration causes a lowered 363 surface temperature and therefore a decreased vapour pressure at the surface, reducing transpiration (Becker \& Fricke, 1996). This effect, also known as evaporative cooling, is more noticeable at high water vapour pressure differences. In this situation evaporation has a 
considerable effect on the driving force and consequently on transpiration (Sastry, 1985).

367 However, respiration increases the product's surface temperature because of heat generation and this increases water vapour pressure at the surface, increasing transpiration (Becker \& Fricke, 1996). This effect, also referred to as respiratory heat generation, is usually low for moderate water vapour pressure but can grow into a dominant factor at RH close to saturation. The respiration phenomena produces an additional mass loss due to carbon loss but it is considered negligible (Sastry, 1985).

\section{Moisture evolution in packaged fresh horticultural produce}

375 Packaging of FFV leads to accumulation of moisture in the headspace as it acts as an additional barrier for moisture transfer. The main source of this moisture is the product itself, however, temperature fluctuations along the supply chain also plays an important role for moisture evolution and condensation (Powers \& Calvo, 2003). Factors affecting moisture transfer and RH in packaged fresh produce are water vapour permeability of the packaging films, transpiration and respiration of product, and storage conditions (Lu, Tang, \& Lu, 2013).

381 Therefore, selection of appropriate packaging materials is one of the essential steps for achieving optimum humidity conditions in packaged fresh produce.

The optimum humidity levels vary in each product, yet in order to reach the maximal postharvest life span it should be taken into account (Ben-Yehoshua \& Rodov, 2002). For most FFV the storage conditions should be within $85 \%$ and $98 \%$ RH. Nonetheless, for products such as garlic and onion storage at $\mathrm{RH}$ higher than 70 to $75 \%$ at optimum temperatures results in excessive water absorption leading to rooting, mould development and sprouting (Rodov, Ben-Yehoshua, Aharoni, \& Cohen, 2010). In the review by Paull (1999) the possible effects of temperature and $\mathrm{RH}$ on fresh commodity quality was extensively discussed. The author also provided a detailed summary of optimum RH and temperature as well as shelf life for a wide range of FFV.

392 Current modified atmosphere packaging (MAP) designs consider the respiration rate of 393 products as the only important parameter when selecting target gas barrier properties. 394 However, besides in-package gas composition, it is also essential to take into consideration 395 the in-package humidity level. In order to avoid moisture condensation and accelerated 396 growth of spoilage microorganisms (Caleb et al., 2013; Mahajan et al., 2014; Song, Lee, \& 397 Yam, 2001). The in-package humidity is determined by transpiration and respiration of the fresh produce and water vapour permeability of the packaging material. Most polymeric 
materials (polyethylene, polypropylene or polyvinyl chloride) used in MAP have lower water vapour permeability relative to the TR of fresh produce (Rux et al., 2016; Song et al., 2001). This leads to further development of MAP into a modified atmosphere and humidity package (MAHP) system, since evaporated water molecules from the produce are not effectively transmitted across the packaging film and prevail within the package. Hence, the challenge of designing an effective MAHP system is finding a solution to design optimal atmosphere and lessen the risk of in-package moisture condensation while still keeping produce mass loss as low as possible.

\subsection{Moisture condensation dynamics}

Condensation is the process in which water vapour turns into liquid form as a result of temperature differences (Joyce \& Patterson, 1994). The temperature at which this process occurs is known as the dew point temperature (Holcroft, 2015). Condensate will be formed on any product that is at or below the dew point temperature of the surrounding air. For every temperature and RH combination at constant pressure, there is a specific and measurable dew point temperature and in order for condensation to appear the temperature has to fall only by a fraction of a degree (Joyce \& Patterson, 1994). Therefore, dew point measurement is a very useful parameter to anticipate moisture condensation and develop control measures. It can be measured directly by means of special sensors or calculated from temperature and humidity following the known laws of psychometry. Condensation inside packaged fresh produce occurs when water molecules evaporated from the product surface do not transmit through the packaging film and stay within the package (Fig. 4). Horticultural produce specific shape, dimension and surface structure, as well as environmental parameters such as storage temperature, $\mathrm{RH}$, and air flow conditions around the produce have a direct impact on the intensity of condensation process (Rodov et al., 2010).

Condensation inside packages of FFV represents a threat to the product quality and safety. It is almost inevitable to avoid moisture condensation in the entire postharvest supply chain due to temperature fluctuations. However, there are some recommendations that can be taken into account in order to minimise the condensation this include: i) storage of the product under strict temperature control; ii) maintenance of a continuous cold chain; iii) perform packaging operation under cold condition; iv) temperature conditioning of the packaging material; v) cool the product to above dew point temperature until they are packed and then cool it to the desired storage temperature; and, v) faster warming of cold fruit in order to reduce the time that the produce is wet (Holcroft, 2015). 
433 Gottschalk, Linke, Mészáros, and Farkas (2007) developed a model that predicts the 434 condensation and transpiration process on a single fruit under varying ambient conditions 435 along storage time. The model was validated using eight fruits in an open container. Linke 436 and Geyer (2013) determined the condensation dynamics and intensity within plastic film 437 packaging for fruit under fluctuating external temperatures. Using packages of plums as a test 438 case, the authors showed that moisture condensation process occurred with time-delayed and 439 superimposed varying intensities on the surface of the fruit, inner film surface, and inner tray 440 walls (Fig. 5). Moisture condensation in the inner film surface was mainly influenced by flow 441 conditions, external temperature amplitude, and in the inner air volume. On the contrary, 442 moisture condensation on fruit surface was caused primarily by temperature amplitude and 443 cycle time. In summary, for the studied cycle time of $240 \mathrm{~min}$, the condensate remained for $44453 \%, 51 \%$ and $42 \%$ of the cycle time on the inner wall of the tray, plum surface and 445 underneath film, respectively. Further detailed investigations are needed to evaluate and 446 simulate moisture condensate formation via integrative mathematical modelling. Such model 447 can be developed using water vapour related characteristics of packaging materials (water 448 vapour permeability, macro and micro perforations), and physiological characteristics of 449 product (respiration and transpiration) as well as external storage environment (temperature, 450 humidity and air flow).

\subsection{Moisture condensation control strategies}

\section{$453 \quad$ 3.2.1 Moisture absorbers}

454 This involves the use of various hygroscopic substrates or substances to attract and hold water 455 molecules from the surrounding environment. Desiccant and papers pads are used to wrap fresh produce in order to mitigate moisture accumulation (Ozdemir \& Floros, 2004). The use of these salts and polyols packages offers an alternative way to avoid moisture condensation inside the package. It has been shown to have beneficial effect on the shelf life of FFV by reducing microbial growth and preserving colour attributes. Mahajan, Rodrigues, Motel, and Leonhard (2008b) also developed a moisture absorber. Fast absorbing moisture absorbers such as calcium chloride $\left(\mathrm{CaCl}_{2}\right)$, potassium chloride $(\mathrm{KCl})$ and sorbitol were mixed with a slow absorbing desiccant such as bentonite in different proportions. Overall results showed that the appearance of mushrooms improved when $5 \mathrm{~g}$ of mixed desiccant was packed in 250 $\mathrm{g}$ of mushroom punnet compared to those packed without desiccant. 
proportions. The change in moisture content of each of the mixed desiccants was measured at regular intervals up to $5 \mathrm{~d}$ at $10{ }^{\circ} \mathrm{C}$. Results showed that optimised desiccant mixture, which contained $0.5,0.26$ and $0.24 \mathrm{~g} \mathrm{~g}^{-1}$ of $\mathrm{CaO}, \mathrm{CaCl}_{2}$ and sorbitol, respectively, and had a moisture

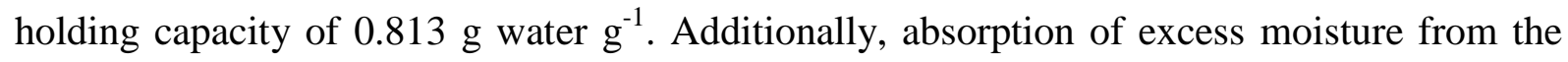
headspace, keeps RH inside the package low (Shirazi \& Cameron, 1992). Also, the use of desiccants for FFV with high water activity might lead to excessive moisture loss. Hence, careful application of desiccants based on detailed research is needed.

\subsubsection{Perforated films}

Micro-perforated packaging films are commonly used in fresh produce packaging to enhance $\mathrm{O}_{2}$ and $\mathrm{CO}_{2}$ gas permeability and control moisture around FFV. Such packaging films have the advantage to avoid in-package anaerobiosis and therefore may extend the shelf-life and maintain quality of FFV (Jo et al., 2013; Hussein, 2015). Almenar et al. (2007) studied the behaviour of strawberries packaged with two continuous and three micro-perforated films (with different gas permeability) with the purpose of obtaining equilibrium atmospheres of diverse compositions. Results showed that micro-perforated films with one and three holes provided adequate $\mathrm{CO}_{2}$ and $\mathrm{O}_{2}$ equilibrium concentrations. However, micro-perforated films do not allow for effective diffusion of water vapour into the environment leading to saturated humidity, moisture condensation and deterioration of fresh packaged horticultural produce (Rodov et al., 2010).

Perforations in a polymeric film is based on a compromise principle since perforations affect the film's permeability to $\mathrm{O}_{2}$ and $\mathrm{CO}_{2}$ to a higher extend than to water vapour. With macroperforated packaging films, it is nearly impossible to achieve MA equilibrium, and prevent excessive mass loss and shrivelling of FFV. In ideal packaging, the humidity level should be low enough to prevent moisture condensation but sufficiently high enough to reduce product mass loss, while also having an optimal atmosphere (Rodov et al., 2010).

\subsubsection{Individual shrink-wrapping}

Individual shrink wrapping (ISW) is a passive form of MAP in which a polymer film with selective permeability to $\mathrm{CO}_{2}, \mathrm{O}_{2}$, ethylene and water is used to pack individual fresh produce in order to maintain its freshness (Dhall, Sharma, \& Mahajan, 2012; Megías et al., 2015). The main advantages of this technology are reduced mass loss, minimised fruit deformation, reduced chilling injuries and decay (Dhall et al., 2012). Rodov et al. (2010) reported that shrink wrapping is also efficient in controlling moisture condensation due to a very small 
501 headspace volume and negligible temperature differences between the product and the film 502 surface.

503 Rao, Rao, and Krishnamurthy (2000) studied the effect of MAP and shrink wrapping on the 504 shelf life of cucumber. Results showed that shrink wrapping with polyethylene film can 505 extend the shelf life of cucumber for up to $24 \mathrm{~d}$ at $10^{\circ} \mathrm{C}$. Megías et al. (2015) studied the 506 effect of ISW on the postharvest performance of refrigerated fruit from two zucchini cultivars 507 that differ in their sensitivity to cold storage. Results indicated that ISW zucchini packaging 508 led to improved tolerance to chilling simultaneously with a decrease in oxidative stress, 509 respiration rate and ethylene production. Despite the positive results, this approach is limited 510 to spherical or cylindrical products (e.g. cucumber) because if any part of the product is not in 511 contact with the film then it will lead to moisture accumulation (Rodov et al., 2010).

\section{$513 \quad 3.2 .4$ Enhanced water vapour permeable films}

514 Various polymers have been developed with relatively high permeability towards water 515 vapour compared to the commonly used polymeric films such as polypropylene or 516 polyethylene. These include co-extruded and bio-degradable polymeric films with enhanced water vapour permeability. Co-extruded films consist of blends of different hydrophilic polyamides with other polymeric and non-polymeric compounds. The different blends allow manufacturing materials varying in water vapour permeability, in accordance with required in-package RH levels (Rodov et al., 2010).

521 As an example, Aharoni et al. (2008) used a co-extruded packaging film Xtend® (StePac, 522 Tefen, Israel) and reported that Xtend ${ }^{\circledR}$ can effectively modify both atmospheric composition 523 and RH inside packaging containing various FFV. Similarly, cellulose-based NatureFlex ${ }^{\mathrm{TM}}$ 524 (Innovia films, Cumbria, UK) polymeric films also held a good potential for application in 525 packaging of fresh produce as it has a very high water permeability $\left(200 \mathrm{~g} \mathrm{~m}^{-2} \mathrm{~d}^{-1}\right.$ at $25{ }^{\circ} \mathrm{C}$ 526 and $75 \% \mathrm{RH})$ as against the conventional polypropylene film with $0.8 \mathrm{~g} \mathrm{~m}^{-2} \mathrm{~d}^{-1}$ water 527 permeability (Sousa-Gallagher et al., 2013). Also, water vapour transmission rate (WVTR) of 528 cellulose based NatureFlex ${ }^{\mathrm{TM}}$ polymeric films has been shown to increase with the increase 529 RH. Therefore, care must be taken in designing fresh produce packages, as excessively high water permeability can lead to higher product moisture and mass loss. 
533 Singh, Saengerlaub, Stramm, and Langowski (2010) reported on the application of humidity-

534 regulating trays incorporated with varying concentrations of sodium chloride $(\mathrm{NaCl})$ for fresh 535 mushrooms. In this study, different percentages of $\mathrm{NaCl}$ were introduced into the polymer 536 matrix of the film from which trays were produced. The authors found that the amount of 537 water vapour absorbed by the tray is directly proportional to the percentage of salt 538 incorporated in the trays. Rux et al. (2015) also reported the use of humidity-regulating trays 539 for mushrooms. Trays were produced with $\mathrm{NaCl}$ (18\% on a weight basis) between the outer 540 barrier layer (polypropylene) and the inner sealing layer (polypropylene/ ethylene vinyl 541 alcohol/ polyethylene). Results showed that humidity-regulating tray maintained a stable $\mathrm{RH}$ 542 (93\%) inside the package and it absorbed $4.1 \mathrm{~g}$ of water vapour within $6 \mathrm{~d}$ at $7{ }^{\circ} \mathrm{C}$ and $85 \%$ $543 \mathrm{RH}$ storage condition. Yet the absorbed water vapour was not enough to prevent water 544 condensation in the package headspace.

545 Furthermore, Rux et al. (2016) optimised the humidity-regulating tray from a thermoformed 546 multilayer structure: polyethylene (outside)/foamed hygroscopic ionomer (active layer) with 0 547 (T-0 tray) or 12 (T-12 tray) wt.-\% NaCl/hygroscopic ionomer (sealing layer, inside). The 548 amount of water absorbed was 7.6 and $13.2 \mathrm{~g}$ by T-0 and T-12 trays respectively, which 549 indicates that the moisture absorbed by the tray was directly proportional to the amount of salt 550 incorporated into the tray matrix. The addition of salt into polymer matrix of packaging tray 551 represents a novel approach to control in-package humidity for fresh produce. However, 552 further optimisation via mathematical modelling is required for product specific needs.

\section{4. Application of integrative mathematical modelling concept}

555 A packaging system for FFV consists of a respiring produce fully enclosed in a tray type package lidded with permeable film. Changes in the amount of water vapour content inside the package will be dependent on transpirational water loss from the product, water vapour transmitted through the packaging film and the water vapour absorbed by the active moisture control system. As a result the following unsteady-state mass balance equation may be used to describe the rate of change of water vapour in the headspace as a function of time:

$$
\left\{\begin{array}{c}
\text { Water vapour evolution } \\
\text { in a package }
\end{array}\right\}=\left\{\begin{array}{c}
\text { Transpirational water loss } \\
\text { from the product }
\end{array}\right\}-\left\{\begin{array}{c}
\text { Water vapour transfer } \\
\text { through packaging film }
\end{array}\right\}-\left\{\begin{array}{c}
\text { Water vapour absored by the active } \\
\text { moisture control system }
\end{array}\right\}
$$

562 There is a wealth of published information on modelling of moisture evolution in fresh 563 produce (Lu et al., 2013; Mahajan et al., 2016; Rennie \& Tavoularis, 2009; Song et al., 2001), 564 yet no systematic study has been conducted to bring all the theoretical models together in a ready to use format. Hence, the sub-sections below present an overview of published models 
566 related to product transpiration, water vapour permeation in perforated packaging system and 567 active moisture control systems.

\subsection{Moisture evolution due to transpiration}

570 There are two approaches commonly used for the mathematical modelling of the transpiration 571 phenomena. The first is based on the diffusion equations of Fick's law (Leonardi et al., 2000; 572 Maguire et al., 2001), and the second approach is based on heat and mass balances (Kang \& 573 Lee, 1998; Lu et al., 2013; Song, Vorsa, \& Yam, 2002). The model presented by Sastry 574 (1985) is the most basic form of a transpiration model: $T R=k_{i}\left(P_{s}-P_{\infty}\right)$. This model was 575 applied primarily to storage situations where steady state conditions prevailed and the key assumption was that temperature of product evaporating surface is the same as its surrounding environment. However, an error is observed in the model at saturated environments (i.e. VPD $=0.0)$ as discussed previously. Therefore, a more complex diffusion model is required to predict transpiration under saturated and stagnant air flow conditions as observed inside packaged fresh produce.

581 Non-linear models for estimating TR based on Fick's first law of diffusion have been reported 582 in the literature, but very little work has been developed in this area, especially for the prediction of TR under MAP systems. There are at least two major reasons why the mathematical modelling of TR for MAP systems are not well developed this includes: i) modelling of this phenomena needs a complete understanding of the dynamic interactions between permeation through the packaging film and evaporation on produce surface as a result of the heat released from respiration; and, ii) existing models are limited to cooling process and bulk storage, which may not be suitable for MAP systems (Song et al., 2002).

589 It is noteworthy to mention that the difference between a $T R_{m}$ and $T R_{s}$ model is the unit of the $590 \mathrm{k}_{\mathrm{s}}$ coefficient. Some authors prefer to use it in terms of mass basis (Caleb et al., 2013; Sousa591 Gallagher et al., 2013) since it is easier to determine the mass of product than its surface area, 592 this makes it a more convenient unit (Sastry, 1985). Other authors emphasised on the 593 significance of expressing transpiration per unit area (Linke, 1997; Xanthopoulos et al., 594 2014), because the area-based transpiration coefficient is not dependent on product mass. An 595 alternative is the use of an area-based transpiration coefficient combined with a statistically 596 determined correlation between surface area and mass for a specific FFV. This approach combines the accuracy of the area based coefficient with the convenience of a quick calculation of the product surface area from the mass. 
Other approach for modelling TR is based on heat and mass balance between the produce and

600 storage atmosphere and is also shown in Table 3. Kang and Lee (1998) developed a

601 transpiration model to predict moisture loss of fresh produce under ambient and controlled

602 atmosphere conditions. In this model the sum of heat energies transferred through natural

603 convection from surrounding air and generated from respiration inside the produce was

604 assumed to be supplied for evaporating moisture on produce surface. Song et al. (2002)

605 proposed a respiration-transpiration model by applying simultaneous heat and mass transfer

606 principles to known physiological behaviour of fresh produce in MAP. Their model applied

607 the assumption that temperature inside the package was equal to the temperature on the

608 surface of the produce and therefore external heat was negligible. Lu et al. (2013) developed a

609 model for transpiration based on mass change of water vapour. Their model considered;

610 respiratory heat generated by produce, heat absorbed by produce, heat absorbed by gas around

611 the produce, heat absorbed by the package and heat change caused by gas transmission across

612 the package.

613 Mathematical models for transpiration, which takes into consideration the various factors

614 affecting TR, are important tools. They help select targeted package designs with optimum

615 WVTR and help estimate fresh produce shelf life (Kang \& Lee, 1998). Models that do not

616 take into account all of the factors can in some cases be satisfactory, but may result in large

617 errors in other cases (Sastry, 1985). However, models that take into account too many factors

618 become complex with limited application flexibility, since some of the parameters may be

619 product specific or not easily measurable. For instance skin thickness, pore fraction in the

620 skin, geometry, thermal diffusivity, and surface cellular structure are factors not easily

621 measured and/or determined (Kang \& Lee, 1998). Therefore, an extremely detailed model

622 might not be as useful and convenient as a well-designed simple model (Tanner, Cleland,

623 Opara, \& Robertson, 2002). Thus, the development of a successful and accurate mathematical

624 model for transpiration depends on the parameters considered and the assumptions made. In

625 addition, respiration plays an important role on the transpiration phenomena for packaged

626 produce and it is important to take this into account when developing a TR model. Both

627 Fick's law and heat and mass transfer approach can incorporate this parameter.

\subsection{Water vapour permeation in perforated packaging systems}

630 Mathematical modelling of mass transfer through perforated packaging is commonly used and

631 has been extensively reported in the literature. A detailed review on perforation mediated

632 packaging systems was recently published by Hussein, Caleb, and Opara (2015). An example 
633 of the application of mathematical modelling for perforated packaging system can be found in 634 the study reported by Fishman, Rodov, and Ben-Yehoshua (1996). The authors developed a 635 mathematical model to study the influence of film perforations on water vapour flux through 636 the perforated film (Eq. 9):

$$
F_{w}=\propto\left(H_{A}-H\right)\left[\frac{S P_{w}}{L}+\frac{\pi R_{h}^{2} N D_{w}}{L+R_{h}}\right]
$$

where $F_{w}$ is the water flux $\left(\mathrm{m}^{3} \mathrm{~h}^{-1}\right) ; \alpha$ is water vapour concentration under saturation vapour pressure which depends on temperature (non-dimensional); $H_{A}$ is $\mathrm{RH}$ in the ambient atmosphere (non-dimensional); $H$ is RH (non-dimensional); $S$ is film area $\left(\mathrm{m}^{2}\right) ; P_{w}$ is water vapour permeability coefficient of the film found from film specifications $\left(\mathrm{m}^{2} \mathrm{~h}^{-1}\right) ; L$ is film thickness (m); $\pi$ is 3.14 (non-dimensional); $R_{h}$ is radius of perforation (m); $N$ is number of pores (non-dimensional); and $D_{w}$ is the diffusion coefficient of water vapour in air $\left(\mathrm{m}^{2} \mathrm{~h}^{-1}\right)$. on RH. Although this model was designed for mango fruit; the proposed equations could still be valid for other commodities if appropriate transpiration coefficients are inserted. BenYehoshua, Rodov, Fishman, and Peretz (1998) applied the model developed by Fishman et al. (1996) and evaluated the effects of perforation on MAP with bell peppers and mangoes. The results showed that perforating the film affects $\mathrm{O}_{2}$ and $\mathrm{CO}_{2}$ concentrations as well as moisture condensation, but not the in-package RH. Lee, Kang, and Renault (2000) developed a model for estimating changes in the atmosphere and humidity within perforated packages of fresh produce. The model was based on mass balances of $\mathrm{O}_{2}, \mathrm{CO}_{2}$, nitrogen gas $\left(\mathrm{N}_{2}\right)$, and water $\left(\mathrm{H}_{2} \mathrm{O}\right)$ and included respiration, transpiration and terms for gas and water vapour transfer through perforations and films. The water vapour exchange rate through the film was modelled based on Fick's law. Similarly, Techavises and Hikida (2008) developed a model based in Fick's law that included atmospheric gas $\left(\mathrm{O}_{2}, \mathrm{CO}_{2}\right.$ and $\left.\mathrm{N}_{2}\right)$ and water vapour exchanges in MAP with perforations. The proposed model showed good prediction of gas concentrations and RH when compared with experimental results. The differential equation used to obtain the volumetric changes inside a perforated MAP of respiring produce for water vapour is presented (Eq. 10):

$$
\frac{d V_{H}(t)}{d t}=n_{p} D_{H}+A_{f} K_{H}\left(P_{H}-P_{T} \frac{V_{H}(t)}{V_{T}(t)}\right)
$$

where $n_{p}$ is number of perforations (non-dimensional); $D_{H}$ is effective permeability of one perforation to water vapour $\left(10^{-6} \mathrm{~m}^{3} \mathrm{~h}^{-1} \mathrm{kPa}^{-1}\right) ; A_{f}$ is surface area of the film package $\left(\mathrm{m}^{2}\right)$; $K_{H}$ is water vapour transpiration rate of film to water vapour $\left(10^{-6} \mathrm{~m}^{3} \mathrm{~m}^{-2} \mathrm{~h}^{-1} \mathrm{kPa}^{-1}\right) ; P_{H}$ is partial pressure of water vapour outside the package $(\mathrm{kPa}) ; P_{T}$ is total pressure inside the 
package $(\mathrm{kPa})$, equal to $101.325 \mathrm{kPa} ; V_{T}(t)$ is total volume of gases inside the package at time $\mathrm{t}\left(10^{-6} \mathrm{~m}^{3}\right)$ and effective permeability $\left(D_{H}\right)$ is a function of perforation diameter $(d)$ in $\mathrm{mm}$ :

$$
D_{H}=2.98 \times 10^{-2} d^{2}+5.37 \times 10^{-1} d+8.22 \times 10^{-1}
$$

669 The authors reported that Eq. 10 is valid for water and atmospheric gases in a temperature range of 5 to $25^{\circ} \mathrm{C}$ and for film thickness smaller than $0.025 \mathrm{~mm}$.

671 Rennie and Tavoularis (2009) also developed a space and time dependent mathematical 672 model for perforation-mediated MAP. The authors considered respiration, transpiration, 673 condensation, heat transfer (evaporative, convective, and conductive), and convective and 674 diffusive transport of $\mathrm{O}_{2}, \mathrm{CO}_{2}$ and $\mathrm{N}_{2}$ and $\mathrm{H}_{2} \mathrm{O}$ through the Maxwell-Stefan diffusion and the 675 convection mass balance model (Eq. 12):

$$
\rho \frac{\partial \omega H_{2} O}{\partial \mathrm{t}}+\nabla\left(-\rho \omega H_{2} O \sum_{j=1}^{n} \operatorname{Dij}\left(\nabla x H_{2} \mathrm{O}+\left(\mathrm{xH}_{2} \mathrm{O}-\omega \mathrm{H}_{2} \mathrm{O}\right) \frac{\nabla \mathrm{p}}{\mathrm{p}}\right)=-\rho \omega \mathrm{H}_{2} \mathrm{O} \cdot u\right.
$$

677

678 where $\rho$ is the gas mixture density $\left(\mathrm{kg} \mathrm{m}^{-3}\right) ; t$ is time $(\mathrm{s}) ; \omega_{\mathrm{H}_{2} \mathrm{O}}$ is $\mathrm{H}_{2} \mathrm{O}$ mass fraction (nondimensional); Dij is the ij component of multicomponent Fick diffusivity $\left(\mathrm{m}^{2} \mathrm{~s}^{-1}\right) ; \mathrm{xH}_{2} \mathrm{O}$ is the mole fraction of water (non-dimensional); $p$ is the total gas mixture pressure (Pa); and $u$ is the velocity vector $\left(\mathrm{m} \mathrm{s}^{-1}\right)$. Their model can be used for steady-state as well as for transient analysis of MAP in a wide range of conditions and is valid to model $\mathrm{H}_{2} \mathrm{O}$ transport in the ambient storage environment, the perforations and in the headspace.

$\mathrm{Li}$, Li, and Ban (2010) reported a model applicable to non-perforated and micro-perforated MAP films which simulates changes in concentrations of various gases, such as $\mathrm{O}_{2}, \mathrm{CO}_{2}$, ethylene $\left(\mathrm{C}_{2} \mathrm{H}_{4}\right)$ and $\mathrm{H}_{2} \mathrm{O}$ inside MAP films over time based on Fick's law of diffusion. While, Mahajan, Rodrigues, and Leflaive (2008c) developed a mathematical model to describe the changes in $W V T R$ as a function of perforation diameter, length and storage temperature in perforation-mediated MAP:

$$
W V T R=2.28 D^{1.72} L^{-0.72} e^{-\frac{12.62}{R T_{S}}}
$$

where $D$ is the perforation diameter $(\mathrm{mm}), L$ is the perforation length $(\mathrm{mm}), R$ is the universal gas constant $\left(0.008314 \mathrm{~kJ} \mathrm{~mol}^{-1} \mathrm{~K}^{-1}\right)$ and $T_{s}$ is the storage temperature $(\mathrm{K})$. These studies present the potential role and application of integrated models in the design of perforationmediated MAP systems for FFV. Their findings also highlight that research needs to develop more flexible and robust models.

\subsection{Active moisture control systems}


A possible solution to control humidity involves the use of moisture absorbers. In this case the package design requires, in addition to packaging specifications, the selection of appropriate desiccants and specification of the amount to be used. This respiration-transpiration model presented by Song et al. (2002) was thus developed into the new model presented by Song et al. (2001). The new model introduced the moisture sorption behaviour of the absorbent (m) as follows:

$$
m=k_{s a} m_{a b}\left(P_{i}-P_{a b}\right)
$$

where $m$ is moisture absorption rate of the absorbent $\left(\mathrm{kg} \mathrm{h}^{-1}\right) ; k_{s a}$ is the absorbent mass transfer coefficient that can be experimentally determined absorbent mass transfer coefficient $\left(\mathrm{kg}_{\text {water }} \mathrm{kg}_{\text {dry matter }}{ }^{-1} \mathrm{~h}^{-1} \mathrm{~atm}^{-1}\right) ; m_{a b}$ is mass of dried absorbent $(\mathrm{kg}) ; P_{i}$ is water vapour pressure inside the package containing absorbent (atm); and $P_{a b}$ is water vapour pressure on the surface of the absorbent (atm). Additionally, $P_{a b}$ is a function of moisture sorption characteristics of absorbents and can be estimated (Eq. 15):

$$
P_{a b}=P_{s p} a_{w}
$$

where $P_{s p}$ is saturated water vapour pressure at constant temperature (atm) and $a_{w}$ is the water activity of the moisture absorbent (non-dimensional), which can be experimentally determined as a function of moisture content. The modified model considered moisture sorption characteristics of absorbent and mass transfer coefficient between adsorbent and package headspace. The model was successfully validated with blueberries using two commercial desiccants, Sanwet (Hoechst Celanese, USA) and Xylitol (Sigma,USA). Although the model predictions were in agreement with experimental data obtained, the amount of condensation inside the packages was not quantified. Therefore, it is not possible to optimise the amount of absorber needed to absorb the excess moisture inside the packages.

Furthermore, Mahajan et al. (2008b) investigated the kinetics of moisture absorption for mixed desiccant $\left(\mathrm{CaCl}_{2}, \mathrm{KCl}\right.$ and sorbitol $)$ at 4,10 , and $16{ }^{\circ} \mathrm{C}$, at different humidity levels (76, 86 and 96\%). Change in moisture content of the mixed desiccant with respect to storage time was fitted to a Weibull distribution model (Eq. 16).

$$
M_{t}=M_{\infty}\left[1-e^{\left(\frac{-t}{\beta}\right)}\right]
$$

where $M_{t}$ is the moisture absorbed $(\mathrm{g})$ at a determined time $t(\mathrm{~d}) ; M_{\infty}$ is moisture holding capacity at equilibrium (g); and $\beta$ is the kinetic parameter, which defines the rate of moisture uptake process and it represents the time (d) needed to accomplish $63 \%$ of the moisture uptake process. The moisture holding capacity was found to be dependent on RH, which 
increased from 0.51 to $0.94 \mathrm{~g}_{\text {water }} \mathrm{g}^{-1}$ desiccant when RH was increased from 76 to $96 \%$.

730 Similarly, Rux et al. (2016) used a Weibull distribution to fit the moisture uptake data 731 obtained from the individual humidity-regulating trays. The authors found that packaged produce with absorbers lost more mass than control samples. Their findings emphasised the importance of selecting the appropriate and correct amount of moisture absorber in order to prevent excessive mass loss and shrivelling of packaged product.

\section{Conclusion and future research needs}

737 Harvested horticultural produce are transported from farm to the final consumer. This process involves many challenges since the product continues both metabolic and physiological activities after harvest. Thus, strict control of temperature and $\mathrm{RH}$ along the supply chain and storage are decisive factors for maintaining quality of FFV. These factors govern the respiration and transpiration processes and consequently degradation of organic substrates and moisture loss. Appropriate packaging of FFV, under optimum storage conditions, offers a possibility to slow down the physiological processes and extend storage life. However, the control of moisture evolution inside packaged horticultural products is complicated due to numerous factors (intrinsic and extrinsic) and the complexity of their interactions. Therefore, application of integrated mathematical models for water relations presents a possible solution; to integrate different factors affecting moisture evolution inside packaged horticultural products. This is vital in order to match the high physiological product requirements and the mass balance of a packaging system in terms of water vapour inside and outside the package.

750 It will provide a guiding tool for all the role players in food packaging industry on package 751 system optimisation such as selection of packaging film, produce amount, package dimensions, perforation, and moisture control strategies; thereby eliminating the "pack-andpray" approach commonly adopted by the food packaging industry.

\section{Nomenclature}

$756 T R_{S} \quad$ transpiration rate per unit surface area $\left(\mathrm{mg} \mathrm{cm}^{-2} \mathrm{~h}^{-1}\right.$ or $\left.\mathrm{mg} \mathrm{cm}^{-2} \mathrm{~s}^{-1}\right)$

$757 T R_{m}$ transpiration rate per unit of initial mass $\left(\mathrm{g} \mathrm{kg}^{-1} \mathrm{~h}^{-1}, \mathrm{mg} \mathrm{kg}^{-1} \mathrm{~h}^{-1}\right.$ or mg kg $\left.\mathrm{s}^{-1}\right)$

$758 \quad R H \quad$ relative humidity $(\%)$

$759 M_{i} \quad$ initial mass of the product ( $\mathrm{mg}, \mathrm{g}$ or $\left.\mathrm{kg}\right)$

$760 M_{t} \quad$ product mass at a determined time ( $\mathrm{mg}, \mathrm{g}$ or $\mathrm{kg}$ )

$761 A_{s} \quad$ initial surface area of the product $\left(\mathrm{cm}^{2}\right.$ or $\left.\mathrm{m}^{2}\right)$

$762 t \quad$ time $(\mathrm{s}, \mathrm{h}$ or $\mathrm{d})$ 
$763 k_{t} \quad$ transpiration coefficient $\left(\mathrm{mg} \mathrm{kg}^{-1} \mathrm{~s}^{-1} \mathrm{MPa}^{-1}\right)$

$764 \quad P_{s} \quad$ water vapour pressure at the evaporating surface of the product (MPa)

$765 \quad P_{\infty} \quad$ ambient water vapour pressure $(\mathrm{MPa})$

$766 k_{s} \quad$ skin mass transfer coefficient $\left(\mathrm{mg} \mathrm{kg}^{-1} \mathrm{~s}^{-1} \mathrm{MPa}^{-1}\right)$

$767 \quad k_{a} \quad$ air film mass transfer $\left(\mathrm{mg} \mathrm{kg}^{-1} \mathrm{~s}^{-1} \mathrm{MPa}^{-1}\right)$

$768 \delta \quad$ diffusion coefficient of water vapour in air $\left(\mathrm{m}^{2} \mathrm{~s}^{-1}\right)$

$769 \tau$, $s \quad$ product skin thickness (m)

$770 \varphi \quad$ fraction of product surface covered by pores (non-dimensional)

$771 h_{d}, \beta \quad$ convective mass transfer coefficient $\left(\mathrm{m} \mathrm{s}^{-1}\right)$

$772 \xi_{1} \quad$ fraction of surface behaving as a free water zone (non-dimensional)

$773 R_{D}, R$ universal gas constant $\left(\mathrm{J} \mathrm{kg}^{-1}{ }^{\circ} \mathrm{C}^{-1}\right)$

$774 T$ ambient temperature $\left({ }^{\circ} \mathrm{C}\right)$

$775 \quad \xi_{2} \quad$ fraction of surface behaving as porous membrane (non-dimensional)

$776 \mu \quad$ resistance factor (non-dimensional)

$777 x_{P} \quad$ volume related water content of air in the intercellular spaces in the centre of the $778 \quad$ produce $\left(\mathrm{mg} \mathrm{cm}^{-3}\right)$

$779 x_{A} \quad$ volume related water content of air unaffected by produce $\left(\mathrm{mg} \mathrm{cm}^{-3}\right)$

$780 r_{B} \quad$ boundary layer resistance in the water vapour pathway $\left(\mathrm{s} \mathrm{cm}^{-1}\right)$

$781 r_{T} \quad$ tissue resistance in the water vapour pathway $\left(\mathrm{s} \mathrm{cm}^{-1}\right)$

$782 x_{p s} \quad$ water content of the air at the produce surface $\left(\mathrm{mg} \mathrm{cm}^{-3}\right)$

$783 \quad \mathrm{~F}_{\mathrm{w}} \quad$ water vapour flux through the perforated film $\left(\mathrm{m}^{3} \mathrm{~h}^{-1}\right)$

$784 \alpha \quad$ water vapour concentration under saturation vapour pressure (non-dimensional)

$785 H_{A} \quad$ relative humidity in the ambient atmosphere (non-dimensional)

$786 \quad H \quad$ relative humidity (non-dimensional)

$787 S, A_{f}, \quad$ surface area of the film $\left(\mathrm{m}^{2}\right)$

$788 P_{w} \quad$ water vapour permeability coefficient of the film $\left(\mathrm{m}^{2} \mathrm{~h}^{-1}\right)$

$789 L \quad L \quad$ film thickness (m)

$790 \pi \quad \pi \quad 3.14$ (non-dimensional)

$791 \quad R_{h} \quad$ radius of perforation (m)

$792 N \quad$ number of pores (non-dimensional)

$793 \mathrm{D}_{\mathrm{w}} \quad$ diffusion coefficient of water vapour in air $\left(\mathrm{m}^{2} \mathrm{~h}^{-1}\right)$

$794 V_{H}(t)$ volume of water vapour inside the package at a determined time $\left(10^{-6} \mathrm{~m}^{3}\right)$

$795 n_{p} \quad$ number of perforations (non-dimensional)

$796 D_{H} \quad$ effective permeability of one perforation to water vapor $\left(10^{-6} \mathrm{~m}^{3} \mathrm{~h}^{-1} \mathrm{kPa}^{-1}\right)$ 
$797 K_{H} \quad$ water vapour transpiration rate of film to water vapour $\left(10^{-6} \mathrm{~m}^{3} \mathrm{~m}^{-2} \mathrm{~h}^{-1} \mathrm{kPa}^{-1}\right)$

$798 P_{H} \quad$ partial pressure of water vapour outside the package $(\mathrm{kPa})$

$799 \quad P_{T} \quad$ total pressure inside the package $(\mathrm{kPa})$

$800 V_{T}(t)$ total volume of gases inside the package at a determined time $\left(10^{-6} \mathrm{~m}^{3}\right)$

$801 d, D$ perforation diameter $(\mathrm{mm})$

$802 \rho \quad$ gas mixture density $\left(\mathrm{kg} \mathrm{m}^{-3}\right)$

$803 \omega \mathrm{H}_{2} \mathrm{O} \mathrm{H}_{2} \mathrm{O}$ mass fraction (non-dimensional)

804 Dij ij component of multicomponent Fick diffusivity $\left(\mathrm{m}^{2} \mathrm{~s}^{-1}\right)$

$805 \mathrm{xH}_{2} \mathrm{O}$ mole fraction of $\mathrm{H}_{2} \mathrm{O}$ (non-dimensional)

$806 \omega j \quad$ mass fraction of $\mathrm{H}_{2} \mathrm{O}$ (non-dimensional)

$807 \quad p \quad$ total gas mixture pressure $(\mathrm{Pa})$

$808 \quad u \quad$ velocity vector $\left(\mathrm{m} \mathrm{s}^{-1}\right)$

$809 L \quad$ perforation length (mm)

$810 T_{s} \quad$ storage temperature $(\mathrm{K})$

$811 m$ moisture absorption rate of the absorbent $\left(\mathrm{kg} \mathrm{h}^{-1}\right)$

$812 k_{s a} \quad$ absorbent mass transfer coefficient $\left(\mathrm{kg}_{\mathrm{H} 2 \mathrm{O}} \mathrm{kg}_{\mathrm{dry}}\right.$ matter $\left.{ }^{-1} \mathrm{~h}^{-1} \mathrm{~atm}^{-1}\right)$

$813 m_{a b}$ is mass of dried absorbent $(\mathrm{kg})$;

$814 P_{i} \quad$ is water vapour pressure inside the package containing absorbent (atm)

$815 P_{a b}$ is water vapour pressure on the surface of the absorbent (atm)

$816 P_{s p} \quad$ saturated water vapour pressure at constant temperature (atm)

$817 a_{w} \quad$ is the water activity of the moisture absorbent (non-dimensional)

$818 M_{t} \quad$ is the moisture absorbed $(\mathrm{g})$ at a determined time (days)

$819 M_{\infty} \quad$ is moisture holding capacity at equilibrium $(\mathrm{g})$

$820 \quad B \quad$ kinetic parameter (non-dimensional) 


\section{Acknowledgment}

This work was supported by Conselho Nacional de Desenvolvimento Científico e Tecnológico (CNPq) through a PhD grant (201623/2015-3) to G.B. Graziele. The Georg Forster Postdoctoral Research Fellowship (HERMES) programme from the Alexander von Humboldt Foundation (Ref. ZAF-1160635-GFHERMES-P) is also appreciated.

\section{References}

Aguirre, L., Frias, J. M., Barry-Ryan, C., \& Grogan, H. (2009). Modelling browning and brown spotting of mushrooms (Agaricus bisporus) stored in controlled environmental conditions using image analysis. Journal of Food Engineering, 91(2), 280-286.

Aharoni, N., Rodov, V., Fallik, E., Porat, R., Pesis, E., \& Lurie, S. (2008). Controlling humidity improves efficacy of modified atmosphere packaging of fruits and vegetables. Paper presented at the EURASIA Sym. on Quality Management in Postharvest Systems. Acta Horticulturae (ISHS) 804: 121-128.

Almenar, E., Del-Valle, V., Hernández-Muñoz, P., Lagarón, J. M., Catalá, R., \& Gavara, R. (2007). Equilibrium modified atmosphere packaging of wild strawberries. Journal of the Science of Food and Agriculture, 87(10), 1931-1939.

Azevedo, S., Cunha, L. M., Mahajan, P. V., \& Fonseca, S. C. (2011). Application of simplex lattice design for development of moisture absorber for oyster mushrooms. Procedia Food Science, 1, 184-189.

Baltaci, D., Linke, M., \& Geyer, M. (2010). Transpiration loss of fresh produce in transport packages - a base for a shelf life prediction model. Paper presented at the 6th International Postharvest Symposium. Acta Horticulturae (ISHS) 877: 1351-1353.

Becker, B. R., \& Fricke, B. A. (1996). Transpiration and respiration of fruits and vegetables New Developments in Refrigeration for Food Safety and Quality (Refrigeration science and technology) (pp. 110-121): International Institute of Refrigeration, Paris, France \& American Society of Agricultural Engineers.

Becker, B. R., \& Fricke, B. A. (2001). A numerical model of commodity moisture loss and temperature distribution during refrigerated storage. Acta Hort. Paper presented the II International Symposium on Application of Modelling as an Innovative Technology in the Agri-Food Chain. Acta Horticulturae (ISHS) 566: 431-436.

Beckles, D. M. (2012). Factors affecting the postharvest soluble solids and sugar content of tomato (Solanum lycopersicum L.) fruit. Postharvest Biology and Technology, 63(1), 129140.

Ben-Yehoshua, S., \& Rodov, V. (2002). Transpiration and water stress. In J. Barz \& J. K. Brecht (Eds.), Postharvest Physiology and Pathology of Vegetables (pp. 111-159). NY, USA: Marcel Dekker.

Ben-Yehoshua, S., Rodov, V., Fishman, S., \& Peretz, J. (1998). Modified-atmosphere packaging of fruits and vegetables: reducing condensation of water in bell peppers and mangoes. Acta Horticulturae (ISHS) 464: 387-392.

Caleb, O. J., Mahajan, P. V., Al-Said, F. A., \& Opara, U. L. (2013). Transpiration rate and quality of pomegranate arils as affected by storage conditions. CyTA - Journal of Food, 11(3), 199207. 
Castellanos, D. A., \& Herrera, A. O. (2015). Mathematical models for the representation of some physiological and quality changes during fruit storage. Journal of Postharvest Technology, 03(01), 18-35.

Dhall, R. K., Sharma, S. R., \& Mahajan, B. V. C. (2012). Effect of shrink wrap packaging for maintaining quality of cucumber during storage. Journal of food science and technology, 49(4), 495-499.

Fishman, S., Rodov, V., \& Ben-Yehoshua, S. (1996). Mathematical Model for Perforation Effect on Oxygen and Water Vapor Dynamics in Modified-Atmosphere Packages. Journal of Food Science, 61(5), 956-961.

Fockens, F. H., \& Meffert, H. F. T. (1972). Biophysical properties of horticultural products as related to loss of moisture during cooling down. Journal of the Science of Food and Agriculture, 23(3), 285-298.

Fonseca, S. C., Oliveira, F. A. R., \& Brecht, J. K. (2002). Modelling respiration rate of fresh fruits and vegetables for modified atmosphere packages: a review. Journal of Food Engineering, 52(2), 99-119.

Gomez Galindo, F., Herppich, W., Gekas, V., \& Sjoholm, I. (2004). Factors affecting quality and postharvest properties of vegetables: integration of water relations and metabolism. Crit Rev Food Sci Nutr, 44(3), 139-154.

Gottschalk, K., Linke, M., Mészáros, C., \& Farkas, I. (2007). Modeling Condensation and Evaporation on Fruit Surface. Drying Technology, 25(7-8), 1237-1242.

Herppich, W. B., Mempel, H., \& Geyer, M. (1999). Effects of postharvest mechanical and climatic stress on carrot tissue water relations. Postharvest Biology and Technology, 16(1), 4349.

Herppich, W. B., Mempel, H., \& Geyer, M. (2001). Osmotic and elastic adjustment, and product quality in cold-stored carrot roots (Daucus carota L.). Gartenbauwissenschaft 66(1): 2026.

Holcroft, D. (2015). Water relations in harvested fresh produce. The Postharvest Education Foundation (PEF). PEF White Paper No. 15-01.

Hussein, Z., Caleb, O. J., \& Opara, U. L. (2015). Perforation-mediated modified atmosphere packaging of fresh and minimally processed produce-A review. Food Packaging and Shelf Life, 6, 7-20.

Jo, Y. H., Kim, N. Y., An, D. S., Lee, H. J., \& Lee, D. S. (2013). Modified atmosphere container equipped with gas diffusion tube automatically controlled in response to real-time gas concentration. Biosystems Engineering, 115, 250-259.

Joyce, D., \& Patterson, B. (1994). Postharvest water relations in horticultural crops: principles and problems [review].[Conference paper]. ACIAR Proceedings-Australian Centre for International Agricultural Research (Australia).

Kang, J. S., \& Lee, D. S. (1998). A kinetic model for transpiration of fresh produce in a controlled atmosphere. Journal of Food Engineering, 35(1), 65-73.

Kays, S. J., \& Paull, R. E. (2004). Postharvest Biology: Exon Press, Athens, GA, 568 p.

Lee, S. L., Kang, J. S., \& Renault, P. (2000). Dynamics of internal atmosphere and humidity in perforated packages of peeled garlic cloves. International Journal of Food Science \& Technology, 35(5), 455-464.

Leonardi, C., Baille, A., \& Guichard, S. (2000). Predicting transpiration of shaded and non-shaded tomato fruits under greenhouse environments. Scientia Horticulturae, 84(3-4), 297-307.

Li, L., Li, X.-H., \& Ban, Z.-J. (2010). A Mathematical Model of the Modified Atmosphere Packaging (MAP) System for the Gas Transmission Rate of Fruit Produce. Food Technology and Biotechnology, 48(1), 71-78. 
Linke, M. (1997). Modelling and predicting the postharvest behaviour of fresh vegetables. Paper presented at the In Proceedings of 3rd IFAC Workshop on Mathematical and Control Applications in Agriculture and Horticulture, Hannover, Germany.

Linke, M., \& Geyer, M. (2000). Determination of flow conditions close to the produce. Paper presented at the In Improving Postharvest Technologies of Fruits, Vegetables and Ornamentals, Murcia, Spain.

Linke, M., \& Geyer, M. (2001). Postharvest transpiration behavior of vegetables - a new approach. Paper presented at the In Proccedings of the $4^{\text {th }}$ International Conference on Postharvest Science. Acta Horticulturae (ISHS) 553: 487-490, Jerusalem, Israel.

Linke, M., \& Geyer, M. (2013). Condensation dynamics in plastic film packaging of fruit and vegetables. Journal of Food Engineering, 116(1), 144-154.

Lu, L.-x., Tang, Y.-I., \& Lu, S.-y. (2013). A Kinetic Model for Predicting the Relative Humidity in Modified Atmosphere Packaging and Its Application in Lentinula edodes Packages. Mathematical Problems in Engineering, 2013, 8.

Maguire, K. M., Banks, N. H., \& Opara, L. U. (2001). Factors Affecting Weight Loss of Apples Horticultural Reviews (pp. 197-234): John Wiley \& Sons, Inc.

Mahajan, P. V., Caleb, O. J., Singh, Z., Watkins, C. B., \& Geyer, M. (2014). Postharvest treatments of fresh produce. Philos Trans A Math Phys Eng Sci, 372(2017), 1-16.

Mahajan, P. V., Oliveira, F. A. R., \& Macedo, I. (2008a). Effect of temperature and humidity on the transpiration rate of the whole mushrooms. Journal of Food Engineering, 84(2), 281288.

Mahajan, P. V., Rodrigues, F. A. S., Motel, A., \& Leonhard, A. (2008b). Development of a moisture absorber for packaging of fresh mushrooms (Agaricus bisporous). Postharvest Biology and Technology, 48(3), 408-414.

Mahajan, P. V., Rodrigues, F. A. S., \& Leflaive, E. (2008c). Analysis of water vapour transmission rate of perforation-mediated modified atmosphere packaging (PM-MAP). Biosystems Engineering, 100(4), 555-561.

Mahajan, P. V., Rux, G., Caleb, O. J., Linke, M., Herppich, W., \& Geyer, M. (2016). Mathematical model for transpiration rate at 100\% humidity for designing modified humidity packaging. Paper presented at the III International Conference on Fresh-cut Produce. Acta Horticulturae (ISHS), University of California, Davis.

Mahmood, T., Anwar, F., Abbas, M., Boyce, M. C., \& Saari, N. (2012). Compositional variation in sugars and organic acids at different maturity stages in selected small fruits from pakistan. International Journal of Molecular Science, 13(2), 1380-1392.

Megías, Z., Martínez, C., Manzano, S., García, A., Rebolloso-Fuentes, M. d. M., Garrido, D., . . Jamilena, M. (2015). Individual Shrink Wrapping of Zucchini Fruit Improves Postharvest Chilling Tolerance Associated with a Reduction in Ethylene Production and Oxidative Stress Metabolites. PLOS ONE, 10(7).

Mishra, V. K., \& Gamage, T. V. (2007). Postharvest Physiology of Fruit and Vegetables Handbook of Food Preservation, Second Edition (pp. 19-48): CRC Press.

Nobel, P. S. (2009). Chapter 8 - Leaves and Fluxes Physicochemical and Environmental Plant Physiology (Fourth Edition) (pp. 364-437). San Diego: Academic Press.

Ozdemir, M., \& Floros, J. D. (2004). Active food packaging technologies. Critical Reviews in Food Science and Nutrition, 44(3), 185-193.

Paull, R. (1999). Effect of temperature and relative humidity on fresh commodity quality. Postharvest Biology and Technology, 15(3), 263-277.

Powers, T. H., \& Calvo, W. J. (2003). 9 - Moisture regulation Novel Food Packaging Techniques (pp. 172-185): Woodhead Publishing. 
Rao, D. S., Rao, K. G., \& Krishnamurthy, S. (2000). Extension of shelf life of cucumber by modified atmosphere packaging (MAP) and shrink wrapping. Indian Food Packer, 54(5), 65-71.

Rennie, T. J., \& Tavoularis, S. (2009). Perforation-mediated modified atmosphere packaging: Part I. Development of a mathematical model. Postharvest Biology and Technology, 51(1), 19.

Robinson, J. E., Browne, K. M., \& Burton, W. G. (1975). Storage characteristics of some vegetables and soft fruits. Annals of Applied Biology, 81(3), 399-408.

Rodov, V., Ben-Yehoshua, S., Aharoni, N., \& Cohen, S. (2010). Modified Humidity Packaging of Fresh Produce Horticultural Reviews, Volume 37 (pp. 281-329): John Wiley \& Sons, Inc.

Rux, G., Mahajan, P. V., Geyer, M., Linke, M., Pant, A., Saengerlaub, S., \& Caleb, O. J. (2015). Application of humidity-regulating tray for packaging of mushrooms. Postharvest Biology and Technology, 108, 102-110.

Rux, G., Mahajan, P. V., Linke, M., Pant, A., Sängerlaub, S., Caleb, O. J., \& Geyer, M. (2016). Humidity-Regulating Trays: Moisture Absorption Kinetics and Applications for Fresh Produce Packaging. Food and Bioprocess Technology, 9(4), 709-716.

Sastry, S. K. (1985). Moisture losses from perishable commodities: recent research and developments. International Journal of Refrigeration, 8(6), 343-346.

Sastry, S. K., Baird, C. D., \& Buffington, D. E. (1977). Transpiration rates of certain fruits and vegetables. In F. r. o. A. r. p. R.-. 172 (Ed.), Final report on ASHRAE research project RP 172 (pp. 1-146): University of Florida.

Sastry, S. K., \& Buffington, D. E. (1983). Transpiration rates of stored perishable commodities: a mathematical model and experiments on tomatoes. International Journal of Refrigeration, 6(2), 84-96.

Shirazi, A., \& Cameron, A. C. (1992). Controlling Relative Humidity in Modified Atmosphere Packages of Tomato Fruit. HortScience, 27(4), 336-339.

Shirazi, A., \& Cameron, A. C. (1993). Measuring transpiration rates of tomato and other detached fruit. HortScience : a journal of the American Society for Horticultural Science, 28(10), 1035-1038.

Singh, P., Saengerlaub, S., Stramm, C., \& Langowski, H. C. (2010). Humidity regulating packages containing sodium chloride as active substance for packing of fresh raw Agaricus mushrooms. Paper presented at the 4th Int. Workshop Cold Chain Management (ed. Kreyenschmidt J, editor. ), Bonn, Germany: University of Bonn.

Song, Y., Lee, D. S., \& Yam, K. L. (2001). Predicting relative humidity in modified atmosphere packaging system containing blueberry and moisture absorbent. Journal of Food Processing and Preservation, 25(1), 49-70.

Song, Y., Vorsa, N., \& Yam, K. L. (2002). Modeling respiration-transpiration in a modified atmosphere packaging system containing blueberry. Journal of Food Engineering, 53(2), 103-109.

Sousa-Gallagher, M. J., Mahajan, P. V., \& Mezdad, T. (2013). Engineering packaging design accounting for transpiration rate: Model development and validation with strawberries. Journal of Food Engineering, 119(2), 370-376.

Tanner, D. J., Cleland, A. C., Opara, L. U., \& Robertson, T. R. (2002). A generalised mathematical modelling methodology for design of horticultural food packages exposed to refrigerated conditions: part 1, formulation. International Journal of Refrigeration, 25(1), 33-42.

Tano, K., Kamenan, A., \& Arul, J. (2005). Respiration and transpiration characteristics of selected fresh fruits and vegetables. Agronomie africaine, 17(2), 103-115. 
Tano, K., Oulé, M. K., Doyon, G., Lencki, R. W., \& Arul, J. (2007). Comparative evaluation of the effect of storage temperature fluctuation on modified atmosphere packages of selected fruit and vegetables. Postharvest Biology and Technology, 46(3), 212-221.

Techavises, N., \& Hikida, Y. (2008). Development of a mathematical model for simulating gas and water vapor exchanges in modified atmosphere packaging with macroscopic perforations. Journal of Food Engineering, 85(1), 94-104.

Thompson, J. F., Mitchell, F. G., Rumsay, T. R., Kasmire, R. F., \& Crisosto, C. H. (1998). Commercial Cooling of Fruits, Vegetables, and Flowers: University of California, Division of Agriculture and Natural Resources, Oakland, Publication 21567, pp.1 - 61.

Veraverbeke, E. A., Verboven, P., Van Oostveldt, P., \& Nicolaï, B. M. (2003a). Prediction of moisture loss across the cuticle of apple (Malus sylvestris subsp. mitis (Wallr.)) during storage: Part 1. Model development and determination of diffusion coefficients. Postharvest Biology and Technology, 30(1), 75-88.

Veraverbeke, E. A., Verboven, P., Van Oostveldt, P., \& Nicolaï, B. M. (2003b). Prediction of moisture loss across the cuticle of apple (Malus sylvestris subsp. mitis (Wallr.)) during storage: part 2. Model simulations and practical applications. Postharvest Biology and Technology, 30(1), 89-97.

Xanthopoulos, G. T., Athanasiou, A. A., Lentzou, D. I., Boudouvis, A. G., \& Lambrinos, G. P. (2014). Modelling of transpiration rate of grape tomatoes. Semi-empirical and analytical approach. Biosystems Engineering, 124, 16-23. 
(A)

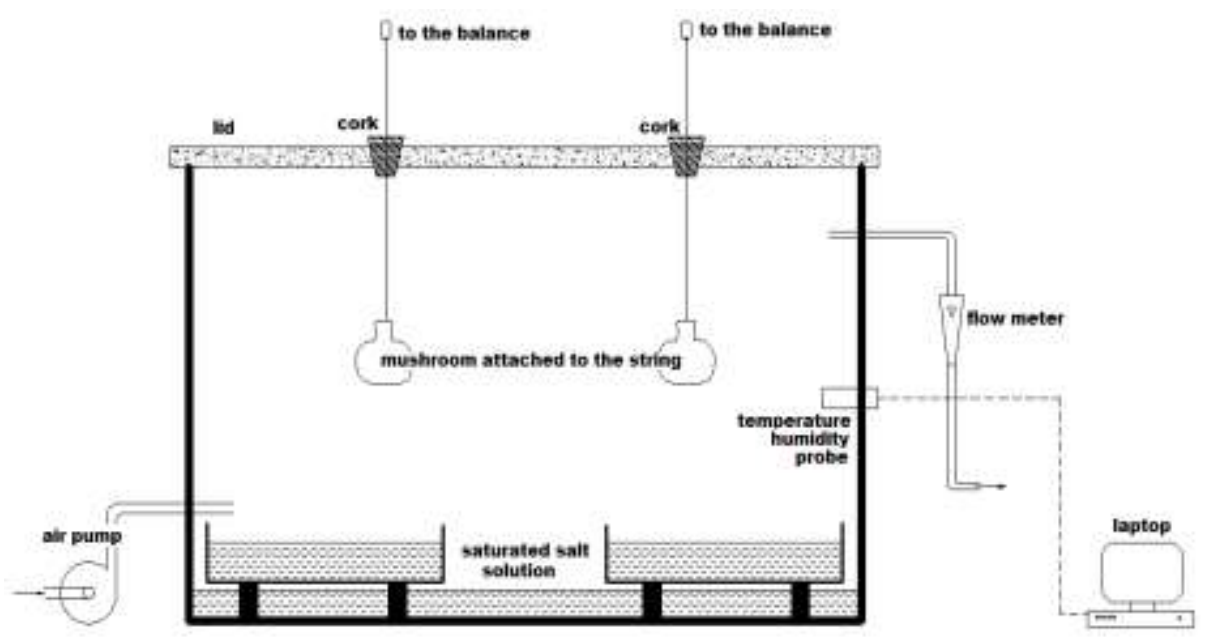

(B)

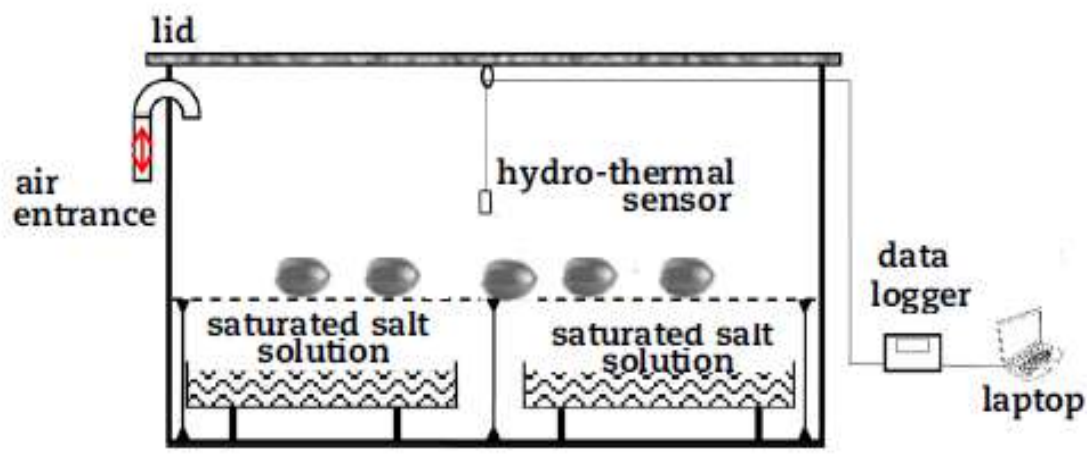

(C)

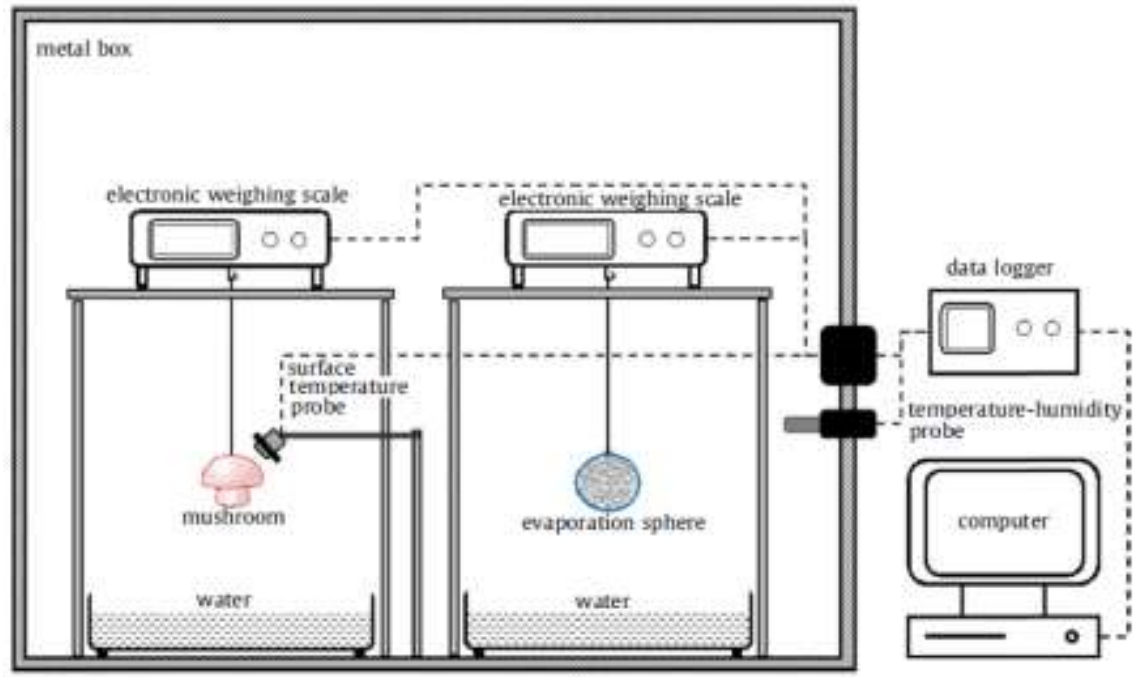

Fig. 1. Schematic representation of a typical experimental setup for used for noncontinuous (A and B) and continuous (C) measurement of produce mass loss (Adopted from Mahajan et al. (2008a), Xanthopoulos et al. (2014), and Rux et al. (2015), respectively) 


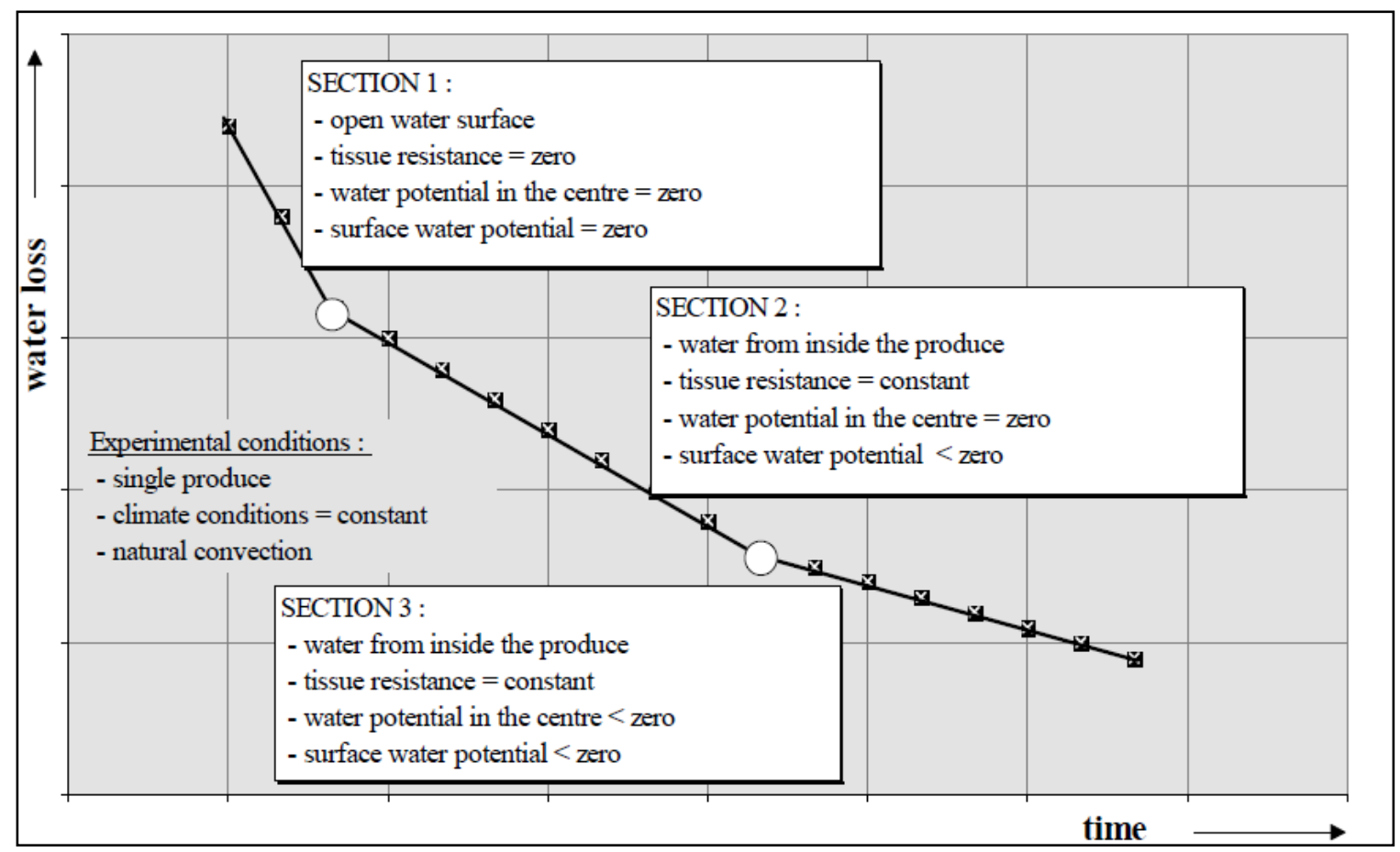

Fig. 2. Sections describing the typical water loss of fruit and vegetables during postharvest storage (Adopted from Linke, 1997)

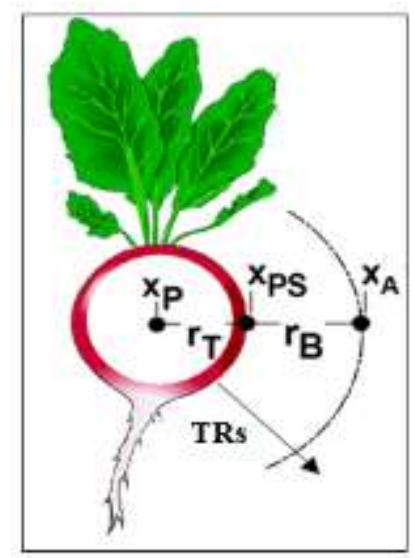

Fig. 3. Basic relations for calculating tissue and boundary layer resistances

(Adopted from Linke, 1998) 


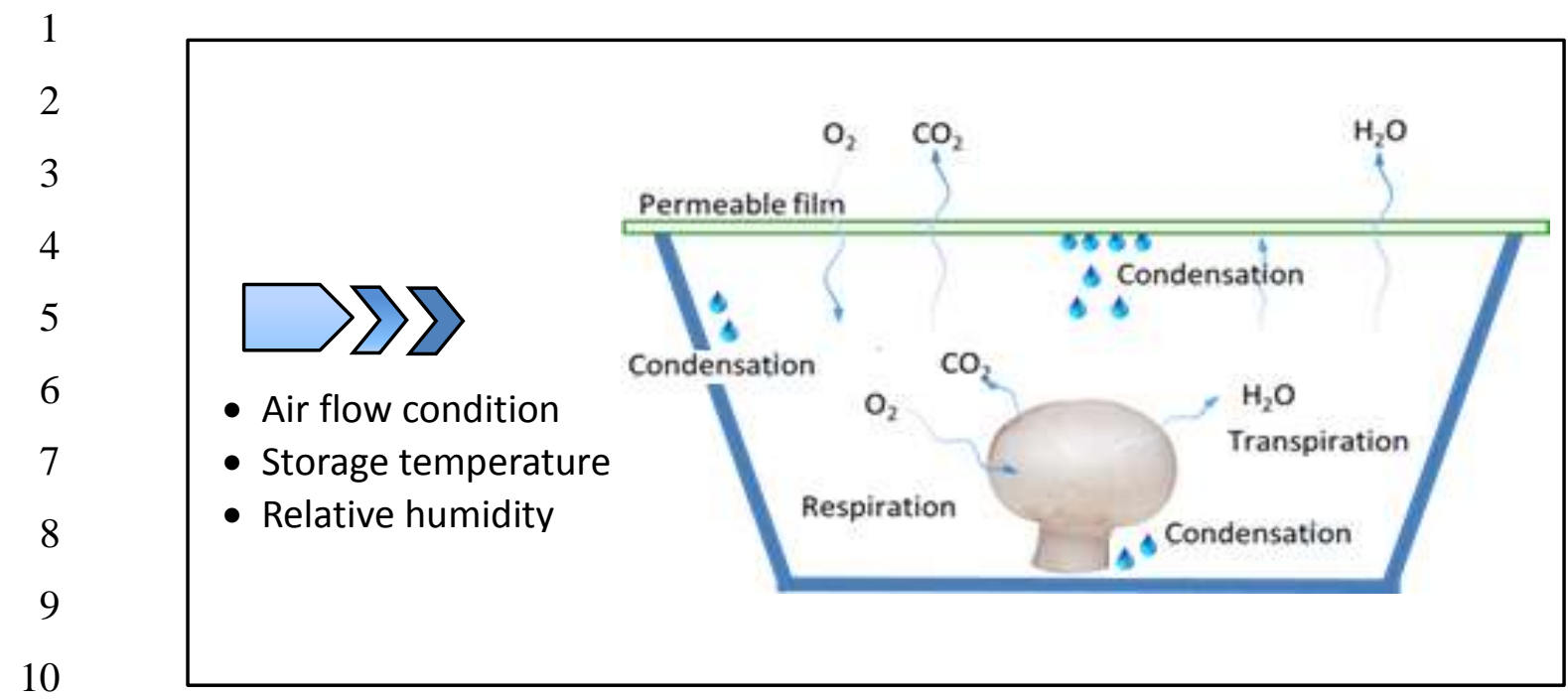

12 Fig. 4. Condensation in packaged fresh produce and environmental parameters impacting the 13 condensation process

14

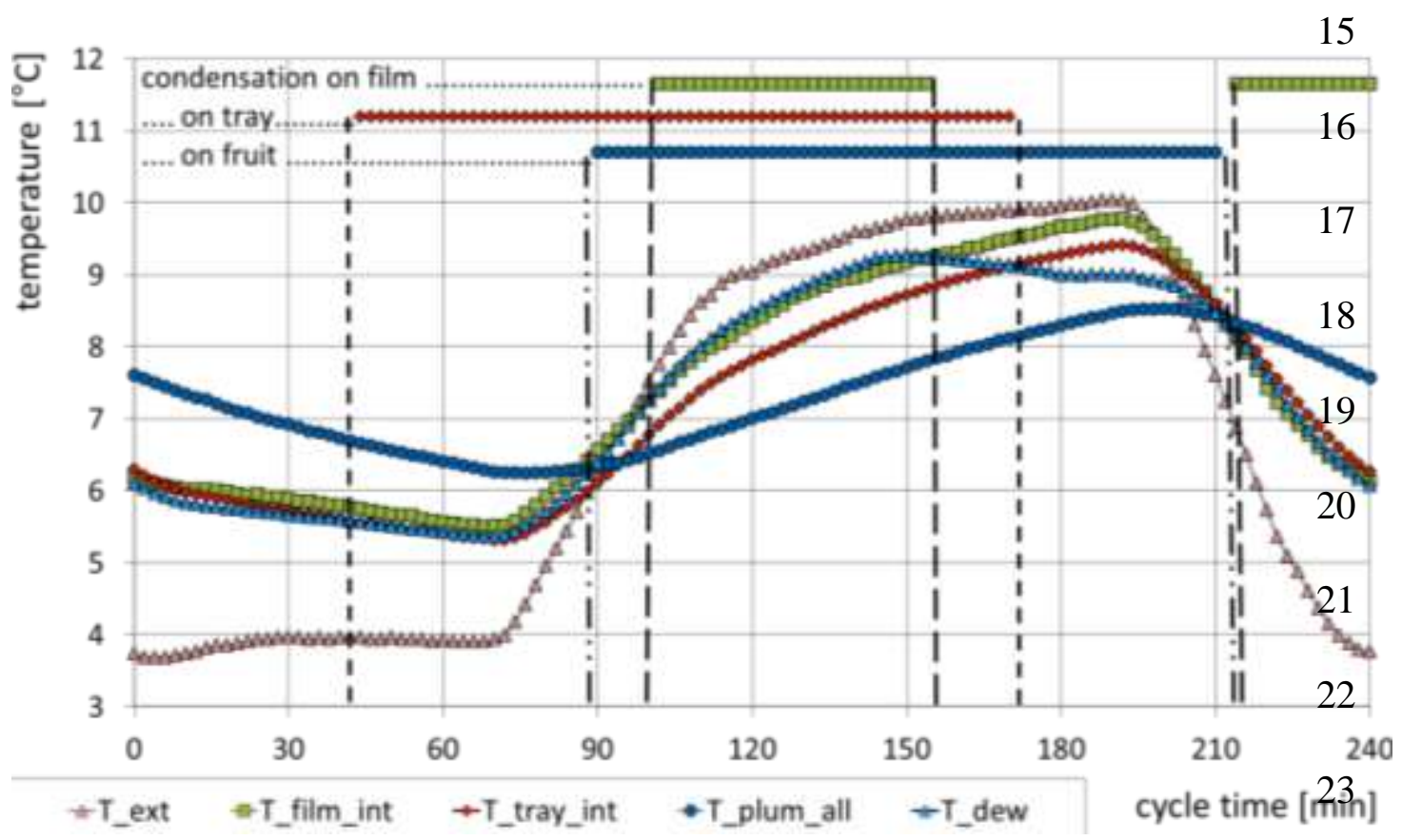

24 Fig. 5. Condensation dynamics in plastic film packaging containing fresh plums 
29 Table 1. Range of transpiration coefficients for some fresh fruit and vegetables

\begin{tabular}{|c|c|c|c|}
\hline Fruit & $\mathrm{k}_{\mathrm{t}}\left(\mathrm{mg} \mathrm{kg}^{-1} \mathrm{~s}^{-1} \mathrm{MPa}^{-1}\right)$ & Vegetables & $\mathrm{k}_{\mathrm{t}}\left(\mathrm{mg} \mathrm{kg}^{-1} \mathrm{~s}^{-1} \mathrm{MPa}^{-1}\right)$ \\
\hline Apple & $16-100$ & Potato & $2-171$ \\
\hline Pear & $10-144$ & Onion & $13-123$ \\
\hline Grapefruit & $29-167$ & Tomato & $71-365$ \\
\hline Orange & $25-227$ & Cabbage & $40-667$ \\
\hline Grapes & $21-254$ & Lettuce & $680-8750$ \\
\hline Plum & $110-221$ & Leek & $530-1042$ \\
\hline Lemon & $139-229$ & Carrot & $106-3250$ \\
\hline Peach & $142-2089$ & Celery & $104-3313$ \\
\hline
\end{tabular}

Source: Thompson et al., 1998 compiled from Sastry et al., 1977

32 Table 2. Tissue resistance of single fresh fruit and vegetables after harvest at natural convection

\begin{tabular}{llll}
\hline Fruit & $\begin{array}{l}\text { Tissue Resistance } \\
\left(\mathbf{r}_{\mathbf{T}}, \mathbf{s ~ c m}^{-\mathbf{1}}\right)\end{array}$ & Vegetables & $\begin{array}{l}\text { Tissue Resistance } \\
\left(\mathbf{r}_{\mathbf{T}}, \mathbf{s ~ c m}^{-\mathbf{1}}\right)\end{array}$ \\
\hline $\begin{array}{l}\text { Strawberries } \\
\text { Plums }\end{array}$ & $3-23$ & Radish tubers & $0.25-1.5$ \\
& $23-38$ & $\begin{array}{l}\text { Carrots (without } \\
\text { leaves) }\end{array}$ & $1-6$ \\
Apples & $170-320$ & $\begin{array}{l}\text { White asparagus } \\
\text { Bell peppers }\end{array}$ & $\begin{array}{l}11-12.5 \\
35-80\end{array}$ \\
\hline
\end{tabular}


49 Table 3. Summary of transpiration rate models applied for various horticultural commodities under different storage conditions and their limitations.

\begin{tabular}{|c|c|c|c|c|c|c|}
\hline Proposed model equation & Unit & Storage conditions & Product & TR Range & Limitation & Reference \\
\hline$\frac{Q_{r} W+h A\left(T-T_{p}\right)}{\Lambda}$ & $\mathrm{kg} \mathrm{h}^{-1}$ & $\begin{array}{l}\text { T: } 0 \\
\text { RH: } 100 \\
\\
\text { T: } 10 \\
\text { RH: } 82\end{array}$ & $\begin{array}{l}\text { Apple } \\
\text { Fresh-cut onion } \\
\text { Fresh-cut green onion }\end{array}$ & $\begin{array}{l}18.4^{2} \text { (normal air) } \\
5.7^{2}\left(1 \% \mathrm{O}_{2}, 1 \% \mathrm{CO}_{2}\right) \\
8.7^{2}\left(3 \% \mathrm{O}_{2}, 3 \% \mathrm{CO}_{2}\right) \\
447^{2} \text { (normal air) } \\
\left.363^{2} \text { (normal air }\right)\end{array}$ & $\begin{array}{l}\text { Model was not validated; not } \\
\text { tested in MAP (tested in controlled } \\
\text { atmosphere) }\end{array}$ & Kang and Lee, 1998 \\
\hline$\frac{Q_{r} W+W C_{s} \frac{d T_{s p}}{d t}}{\Lambda}$ & $\mathrm{kg} \mathrm{h}^{-1}$ & $\begin{array}{l}\text { T: } 15,25 \\
\text { RH: } 10,60\end{array}$ & Blueberry & NG & $\begin{array}{l}\mathrm{T} \text { inside the package was } \\
\text { considered equal to the } T_{\mathrm{s}}\end{array}$ & Song et al., 2002 \\
\hline$\rho . K_{i} \cdot\left(a_{w i}-a_{w}\right) \cdot\left(1-e^{-a T}\right)$ & $\mathrm{mg} \mathrm{cm}^{-2} \mathrm{~h}^{-1}$ & $\begin{array}{l}\text { T: } 4,10,16 \\
\text { RH: } 76,86,96\end{array}$ & Mushrooms & $0.14-2.5^{1}$ & $\begin{array}{l}\text { Model not tested in MAP; does not } \\
\text { consider RR }\end{array}$ & Mahajan et al., 2008 \\
\hline$K_{i \cdot}\left(a_{w i}-a_{w}\right) \cdot\left(1-e^{-a T}\right)$ & $\mathrm{g} \mathrm{kg}^{-1} 24 \mathrm{~h}^{-1}$ & $\begin{array}{l}\text { T: } 5,10,15 \\
\text { RH: } 76,86,96\end{array}$ & Pomegranate arils & $48-698^{2}$ & $\begin{array}{l}\text { Model not tested in MAP; does not } \\
\text { consider RR }\end{array}$ & Caleb et al., 2013 \\
\hline & $\mathrm{g} \mathrm{kg}^{-1} \mathrm{~h}^{-1}$ & $\begin{array}{l}\text { T: } 5,10,15 \\
\text { RH: } 76,86,96\end{array}$ & Strawberries & $240-1160^{2}$ & Model does not consider RR & $\begin{array}{l}\text { Sousa-Gallagher } \\
\text { et al., } 2013\end{array}$ \\
\hline $\begin{array}{l}K_{i} \cdot e^{\left[-\frac{E_{a}}{R}\left(\frac{1}{T}-\frac{1}{T} T_{r}\right)\right]} \cdot\left(a_{w i}-a_{w}\right) \rho \cdot K_{i} \cdot e^{\left[-\frac{E_{a}}{R}\left(\frac{1}{T}-\frac{1}{T} T_{r}\right)\right]} \cdot\left(a_{w i}-\right. \\
\left.a_{w}\right)\end{array}$ & $\begin{array}{l}\mathrm{g} \mathrm{kg}^{-1} \mathrm{~h}^{-1} \\
\mathrm{mg} \mathrm{cm}^{-2} \mathrm{~h}^{-1}\end{array}$ & $\begin{array}{l}\text { T: } 10,15,20 \\
\text { RH: } 70,80,92\end{array}$ & Grape tomato & $\begin{array}{l}18-107^{2} \\
0.012-0.058^{1}\end{array}$ & $\begin{array}{l}\text { Model not validated; does not } \\
\text { consider RR }\end{array}$ & $\begin{array}{l}\text { Xanthopoulos } \\
\text { et al., } 2014\end{array}$ \\
\hline $\begin{array}{l}K_{i \cdot} \cdot\left(a_{w i}-a_{w}\right) \cdot\left(1-e^{-a T}\right) \\
+8.6 R R_{C O 2, r} \cdot e^{\left.\frac{-E a}{R} \mid \frac{1}{(T+273)}-\frac{1}{(T r+273)}\right]}\end{array}$ & $\mathrm{mg} \mathrm{kg}^{-1} \mathrm{~h}^{-1}$ & $\begin{array}{l}\text { T:13 } \\
\text { RH: } 100\end{array}$ & $\begin{array}{l}\text { Mushrooms } \\
\text { Strawberries } \\
\text { Tomato }\end{array}$ & $\begin{array}{l}713^{2} \\
122^{2} \\
17.6^{2}\end{array}$ & Model was not validated & Mahajan et al., 2016 \\
\hline
\end{tabular}

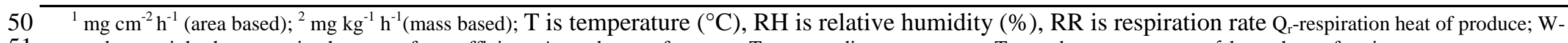
produce weight; $h$-convective heat transfer coefficient; A-produce surface area; $\mathrm{T}_{\mathrm{s}}$-surrounding temperature; Tp-produce temperature; $\Lambda$-latent heat of moisture

evaporation/vaporization; $\mathrm{C}_{\mathrm{s}}$ is specific heat of the produce, $\mathrm{T}_{\mathrm{sp}}$ product surface temperature; $\rho$-water density; $\mathrm{K}_{\mathrm{i}}$-mass transfer coefficient; $\mathrm{a}_{\mathrm{w}}$-water activity of the container; $\mathrm{a}_{\mathrm{wi}}$

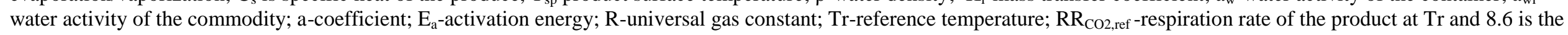
conversion factor for obtaining TR from the respiratory heat generation, NG is not given. 